\title{
The Influence of Climate Variability on Holoplanktonic Polychaetes Populations of Ocean Sector of the Colombian Pacific Basin
}

\author{
José Manuel Gutiérrez-Salcedo1,2* (), Adibe Cárdenas-Oliva ${ }^{2}$ (D) Néstor H. Campos ${ }^{3}$ (i) \\ ${ }^{1}$ Marine Fauna of Colombia, Biodiversity and Uses Research Group, Universidad Nacional de Colombia, \\ Caribbean Headquarters, Santa Marta, Colombia \\ ${ }^{2}$ Museo de Historia Natural Marina de Colombia-MHNMC (Makuriwa), Instituto de Investigaciones Marinas y \\ Costeras-INVEMAR, Santa Marta, Colombia \\ ${ }^{3}$ Instituto de Estudios en Ciencias del Mar-CECIMAR. Universidad Nacional de Colombia, \\ Caribbean Headquarters, Santa Marta, Colombia \\ Email: *jmgutierrezsa@unal.edu.co
}

How to cite this paper: Gutiérrez-Salcedo, J.M., Cárdenas-Oliva, A. and Campos, N.H. (2021) The Influence of Climate Variability on Holoplanktonic Polychaetes Populations of Ocean Sector of the Colombian Pacific Basin. Open Journal of Ecology, 11, 317-343. https://doi.org/10.4236/oje.2021.114023

Received: February 28, 2021

Accepted: April 10, 2021

Published: April 13, 2021

Copyright $\odot 2021$ by author(s) and Scientific Research Publishing Inc. This work is licensed under the Creative Commons Attribution International License (CC BY 4.0).

http://creativecommons.org/licenses/by/4.0/

\begin{abstract}
Studies of holoplanktonic polychaetes in the Tropical Eastern Pacific have focused on their systematics and distribution however, population responses related to climate variability are non-existent. Therefore, the present work described for the first time the influence of the climatic variability 2004-2012 on the holoplanktonic polychaetes populations, as well as their relationship to environmental variables. Species of the Alciopidae, Lopadorrhynchidae and Iospilidae families were identified from 85 samples collected in the Pacific Basin of Colombia, contrasting them with the presence of ENSO, and correlating them with the environmental variables of temperature, salinity and chlorophyll- $\alpha$ concentration. Of the 14 species identified, only Lopadorrhynchus cf. henseni and L. cf. brevis increased their densities under El Niño and correlated positively with temperature. Rhynchonereella cf. petersii correlated negatively with temperature; while $R$. cf. gracilis and Pelagobia cf. longicirrata were positively correlated with chlorophyll- $\alpha$ concentration and salinity, respectively. Additionally, with the first description of the environmental ranges of the 14 species identified for the Colombian Pacific basin, it was found that the most commons species presented broader environmental ranges. The results from the current research are consistent with previous studies in other regions of the Pacific and latitudes. The responses of the organisms suggest trophic and mobility trends that were not known for tropical holoplanktonic polychaete species.
\end{abstract}




\section{Keywords}

Temperature, Chlorophyll, Oceanic Province, Tropical Region, El Niño Southern Oscillation-ENOS

\section{Introduction}

The marine zooplankton is composed by many organisms that together help to modulate the life of the planet [1]. In this community are found the holoplanktonic polychaetes; organisms that come from their benthic congeners [2]. They have evolved to fully live their entire life cycle in the water column [3] [4]. The holoplanktonic polychaetes are taxonomically represented by nine families that group about 100 species distributed in all oceans [2] [5], particularly in subtropical and tropical regions [6] [7].

Although holoplanktonic polychaetes are not abundant or diverse in the different oceanic planktonic assemblages, they are frequent [3] [7]. Studies have found that the protein content of holoplanktonic polychaetes is of excellent quality [3] [8]. In addition, it has been shown that they have many feeding strategies, as well as different types of food [2] [9]. These characteristics allow them to be considered as an ecological group of great importance in the planktonic community because they help in the mineralization processes of organic matter and in the transfer of energy to higher trophic levels such as fish larvae [10] [11]. They are also considered by some authors as indicators of water masses, being found in greater abundance with waters from upwelling [4] [12].

Despite these considerations, studies of holoplanktonic polychaetes are scarce compared to other zooplankton groups such as copepod, chaetognaths, and euphausiids [3] [9] [13] [14]. These studies have been carried out based on transoceanic campaigns of the last century e.g. [15] [16], mainly describing species and their geographical distributions to macroscale [17]. In the Pacific Ocean, the most information of this group has been obtained in the Eastern Tropical Pacific Ocean-ETP from the work by Fernández-Âlamo [18], who identified 44 species from five families, with Alciopidae and Lopadorrhynchidae as the most frequent and diverse.

In the Colombian Pacific basin (CPB), which is part of the ETP, few studies have been carried out on holoplanktonic polychaetes. In addition to the three taxonomic works carried out by Fernández-Álamo [18] [19] [20], only one ecological study has been found in the neritic province of the CPB that describes the relationship of the group with the concentration of chlorophyll- $\alpha$, temperature and salinity during 1996 and 1997 [21]. However, the analyses were not performed at the species level. With these four studies, [22] species of holoplanktonic polychaetes have been recorded in the CPB for the Colombian Pacific basin, all extracted from stations located in the Neritic province.

It has become imperative to carry out ecological studies on various biological 
groups to know the different population responses to climate variability and thus complement and improve the understanding of life on the planet, providing new knowledge, as well as data for the predictive models created to understand the effect of climate change [22] [23] [24] [25]. Studies have shown that organisms can have different responses to similar environmental conditions when contrasted between regions [26]. An example of this can be evidenced by the responses of population densities. When the climate variability increases the temperature, salinity or quantity and quality of the available food from the water, population increases of some species have been found [27]. The same response, in the same species, has also been observed when the values of the environmental variables are inversed or have combinations [28] [29].

In the ETP region, one of the main modulators of climate variability is the El Niño Southern Oscillation-ENSO [30] [31] [32]. This event changes environmental conditions by increasing or decreasing sea temperatures, as well as stratifying or mixing the water column [33] [34]. Marine communities have been found to adapt to changes caused by ENSO [35] [36] [37]. In the case of the Colombian Pacific basin, as in the ETP, the studies have focused on the effect and response of warming waters (e.g. El Niño). These studies have found that populations in the Neritic province and coastal region decrease their densities due to the decrease in the quality and quantity of food [21] [38].

However, no works have been found in the literature that attempt to study the response at the population level of the different holoplanktonic polychaetes to climate variability. This has caused gaps in knowledge and a lack of necessary supplies to better understand the dynamics of our ecosystems. Therefore, and considering that described above, the aims of this study were 1) described the influence of climate variability on the populations of some species of holoplanktonic polychaetes present in the oceanic province of the Pacific Basin of Colombia; and 2) described the relation between the presence of the species and their population densities with the environmental variables of temperature and salinity, as well as chlorophyll- $\alpha$ concentration.

\section{Methods}

\subsection{Study Area}

The Region I of the central ETP is located within the Colombian Pacific Basin-CPB [39]. It has an approximate area of $49,000 \mathrm{~km}^{2}$ (14\% of the CPB) (Figure 1) and depths greater than $3000 \mathrm{~m}$. The water column is stable and has no direct influence on coastal environmental factors, making it a sector of purely oceanic water mass [33] [40]. The annual pattern of water temperature and salinity, as well as rainfalls, are modelled by the Tropical Northeast Pacific warm pool, the Inter Tropical Convergence Zone-ITCZ and the ENSO [31] [41].

\subsection{Environmental Variables and Climate Variability}

Monthly time series of temperature, salinity and chlorophyll- $\alpha$ concentration of 


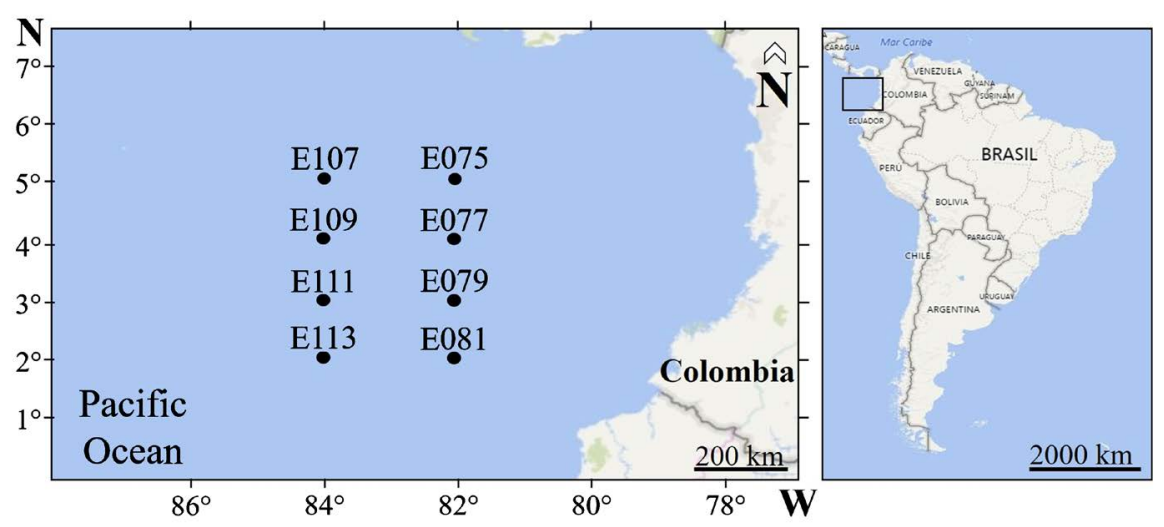

Figure 1. Geographic location of sampling stations in the Colombian Pacific Basin.

the sea surface were used from the works carried out by Cabarcas-Mier [39] and O'Brien et al. [42], who obtained the information from satellite images. The Southern Oscillation Index-SOI [43] was used to identify climate variability caused by El Niño or La Niña events (Appendix-Table A1).

\subsection{Field Sampling}

The ERFEN program established eight stations in the study area (Figure 1). Samples between 2004 and 2012 were annual between September and October. Additional samples were also obtained between the months of February and March of the 2007-2009 period (Appendix-Table A2). To simplify the analyzes, the samples obtained between February and March are considered as the first half of the year (I); while the samples obtained between September and October are the second half of the year (II). Sampling time depended on the arrival of the vessel at each station. All samples could be used because no significant differences were found between population density values obtained at day and night (Mann-Whitney test $\mathrm{p}$-value $>0.05$ ).

The samples were obtained with oblique trawls in the first $200 \mathrm{~m}$ depth using a bongo system with $60 \mathrm{~cm}$ diameter rings, $250 \mu \mathrm{m}$ mesh pore nets and General Oceanic mechanical flowmeter to measure the filtered volume. The samples were fixed and preserved in formalin at $5 \%$ final concentration, following the basic suggestions for handling and storage [44]. More detailed procedures are recorded in Uribe-Palomino et al. [27] and CPPS [45].

\subsection{Laboratory}

A total of 85 samples were used. The analyzes were made with a fraction that corresponded to $25 \%$ of each sample. To do this, each sample had to be divided twice with a Folsom splitter. Polychaetes were removed entirely from each fraction using a stereoscope. Preliminarily, polychaetes were separated at the family level. Only the organisms of the families Alciopidae, Iospilidae and Lopadorrhynchidae were identified and quantified to species level. The Tomoteridae and Typhloscolecidae families, as well as the larvae, were not identified due to 
deterioration of the specimens or the difficulty of identification. The taxonomic identifications were based on the keys of Dales [15], Orensanz and Ramírez [46], Støp-Bowitz [16], Suárez-Moralez et al. [12] and de León-González et al. [47]. Identities and the validation of species were verified in the World Registry of Marine Species [48]. The identified material will be deposited in the biological collections of the Museum of Marine Natural History of Colombia (MHNMC) Makuriwa. The population density was expressed in individuals per 100 cubic meters (ind $/ 100 \mathrm{~m}^{3}$ ).

\subsection{Analysis of Data}

An environmental description of the study area was made before determining the influence given by both, spatial and temporal environmental conditions on the population densities of holoplanktonic polychaetes, as well as the relation with environmental variables.

To establish if the study area was homogeneous, we carry out a hierarchical agglomerative analysis of weighted average similarity-CLUSTER and non-metric multidimensional scaling-NMDS. These analyses were performed from the databases of temperature, salinity, and chlorophyll- $\alpha$, using a triangular similarity matrix from the Euclidean distance algorithm. The analyses were realized using the statistical program Primer-e V.7 [49].

Climate variability was described by plotting monthly Southern Oscillation Index-SOI values between 2004 and 2012, as well as the average SOI values corresponding to the sampling times (i.e., three months before the sampling month, and the sampling month). This sampling time is due to the ecological time of renewal of the zooplankton community [50] [51]. The neutral period was considered when the SOI values were between -0.25 and 0.25 , the presence of El Niño when the values were $<-0.25$, and the presence of La Niña with values $>0.25$. Additionally, anomalies of the environmental variables were calculated for each sampling moment using the analysis of transform Z (E.1) [39]. The general average per month and its standard deviation were calculated from each data set until 2003.

$$
T z=\frac{(x-\bar{X})}{S . D .}
$$

With:

- $T z=$ Transform Z

- $x=$ Individual value

- $\bar{X}=$ Mean

- $S . D .=$ Standard deviation

To determine the influence by both spatial and temporal environmental conditions on the population densities of holoplanktonic polychaetes, graphic descriptions of the distribution and population density of the species were made considering the environmentally formed sectors and the climate variability of the study period. The population density is expressed in individuals per $100 \mathrm{cu}$ - 
bic meters (ind $/ 100 \mathrm{~m}^{3}$ ). To obtain the population density of each species, the following formula was used (E.2):

$$
P d=\frac{(O c * P)}{F . V .} * 100
$$

With:

- $P d=$ Population density

- $O c=$ Organism count

- $P=$ Proportion of the revised sample

- $F . V .=$ Filtered volume

Additionally, non-parametric Kruskal-Wallis tests were carried out with the six most frequent species since they met the minimum statistical requirements of the test. The spatial factors were equivalent to the sectors formed and the temporal factors to the ENSO conditions at the time of sampling. The significant tests were complemented with the Dunn test, which establishes the factor that generated the difference.

Finally, to describe the relation between the presence of the species and their population densities with the environmental variables of temperature, salinity, and chlorophyll- $\alpha$, the environmental ranges of all species were calculated from the presence data. Additionally, environmental variables were correlated with population densities using the Pearson and Spearman tests. Both, the KruskallWallis and Dunn tests and the Spearman and Pearson correlation tests were performed with the statistical package for Excel Real-Statistics v5.4 [52].

\section{Results and Discussion}

The Cluster and NMDS justified divide the study area into three sectors (Figure 2). Figure 3 shows the spatial differences. The northern sector was the warmest and less saline $\left(\bar{X}: 27.5^{\circ} \mathrm{C} \pm 1.0^{\circ} \mathrm{C}\right.$ and $32.4^{\circ} \mathrm{C} \pm 0.7^{\circ} \mathrm{C}$ ), while the southern sector was the less warm and most saline $\left(\bar{X}: 26.1^{\circ} \mathrm{C} \pm 0.8^{\circ} \mathrm{C}\right.$ and $\left.33.3^{\circ} \mathrm{C} \pm 0.7^{\circ} \mathrm{C}\right)$. The central sector presented intermediate values $\left(\bar{X}: 26.8 \pm 0.9^{\circ} \mathrm{C}\right.$ and $32.8^{\circ} \mathrm{C} \pm$ $\left.0.7^{\circ} \mathrm{C}\right)$. The chlorophyll- $\alpha$ concentration, showed similar values among the three sectors ( $\bar{X}$ : north $228.4 \pm 84.4 \mu \mathrm{g} / \mathrm{m}^{3}$; central $270.7 \pm 135.3 \mu \mathrm{g} / \mathrm{m}^{3}$; south $270.1 \pm$ $\left.102.1 \mu \mathrm{g} / \mathrm{m}^{3}\right)$. However, the central sector presented the most extreme peaks and valleys, while the northern sector had the less time variations.

The condition of La Niña predominated between 2004 and 2012, increasing durations and intensities annually. The period of 2010-2011 was the La Niña strongest. The condition of El Niño appeared at the beginning of the period study and at the end of 2009. The neutral periods presented were short, the most prominent being that of 2012 (Figure 4(a)). Sampling time reflected the general annual pattern of ENSO (Figure 4(b)).

The environmental variables allowed sectorizing the study area latitudinally. The highest values were measured in the northern sector and gradually decreased towards the southern sector, which allowed inferring that it was the dominant variable in this spatial delimitation. Additionally, it coincides with the temperature 
(a)

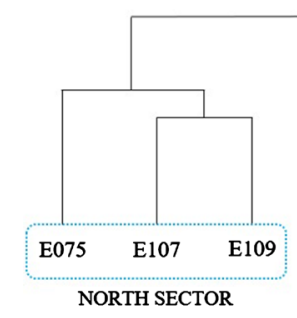

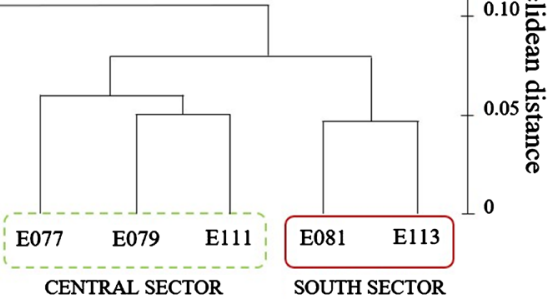

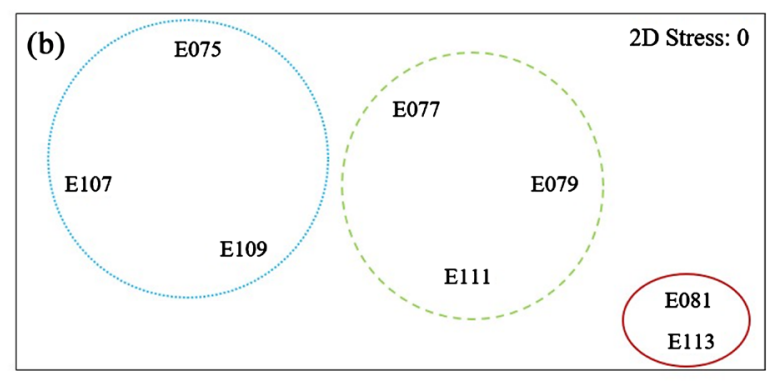

Figure 2. Graphical representation of multivariate non-parametric analyses based on data from environmental variables. (a) Cluster; (b) nMDS.
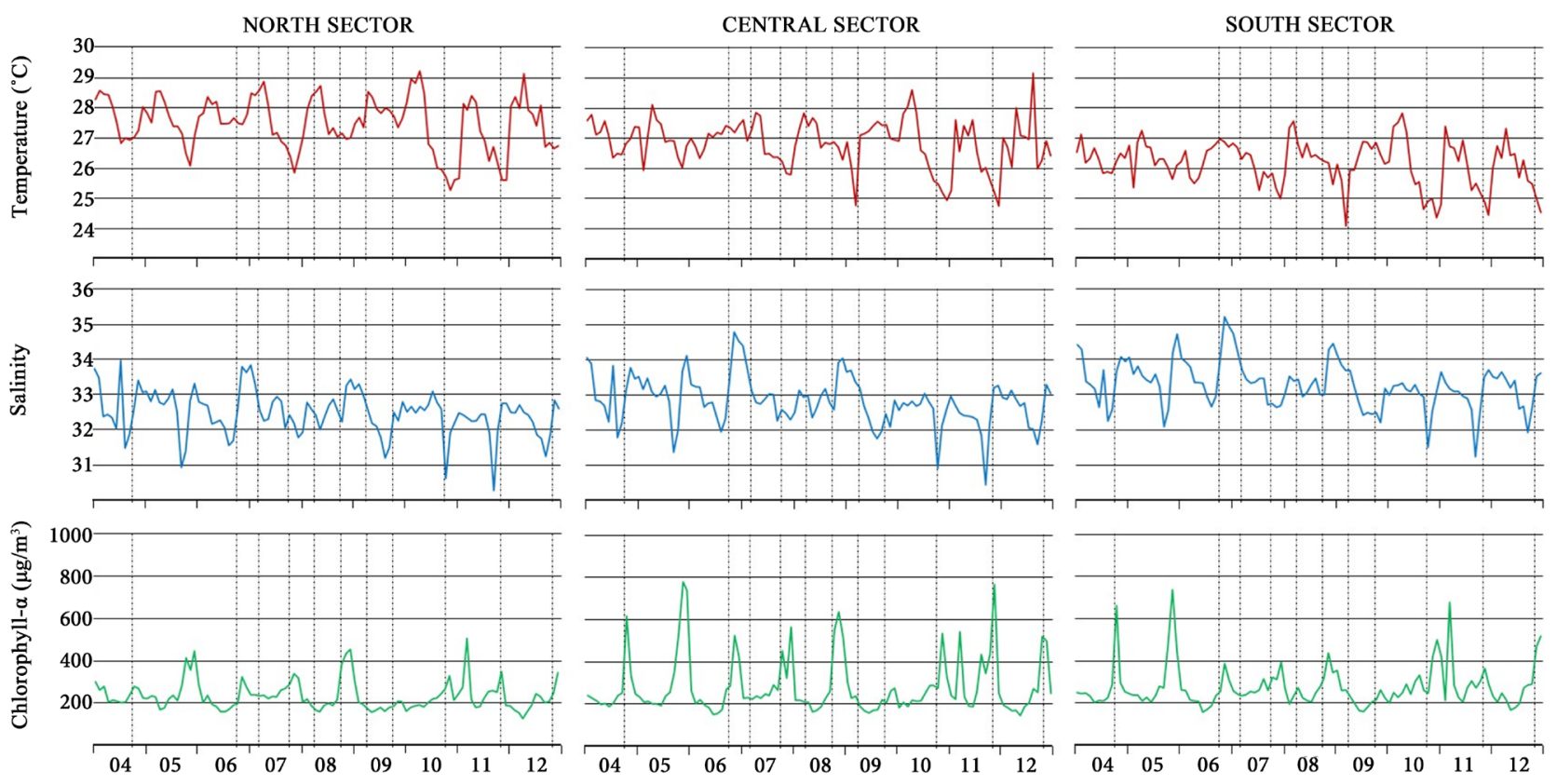

Figure 3. Time series between 2004 and 2012 of environmental values by sector formed in the study area. Vertical lines: sampling month.
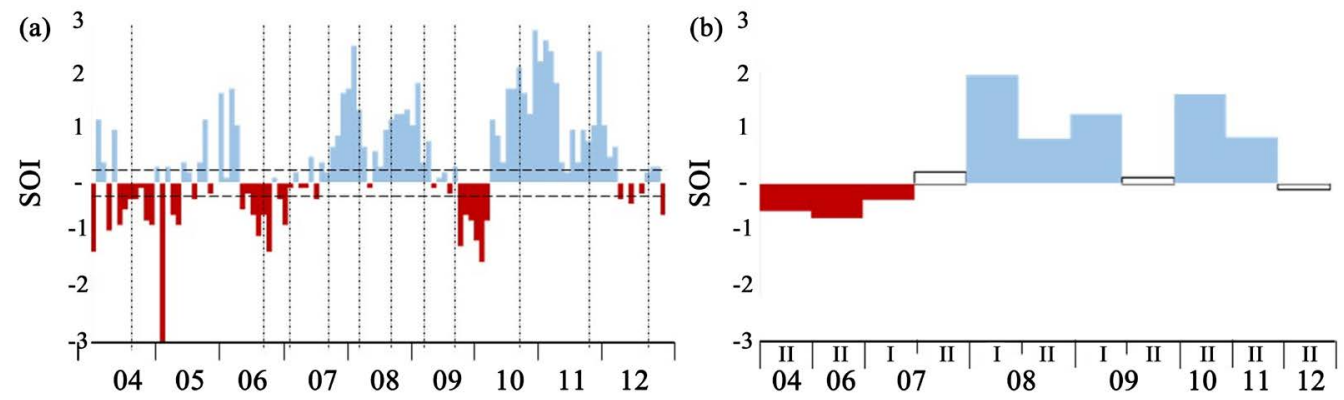

Figure 4. Southern Oscillation Index (SOI) during the 2004-2012 period. (a) SOI monthly. (b) SOI during the sampling time (three months before and the sampling month). Vertical lines: sampling month; horizontal lines: limit chosen for the ENSO influence. I: First semester; II: Second semester (see Methods).

patterns modulated by the Tropical Northeast Pacific warm pool [31], as well as the circulation at the mesoscale level of the region [53]. Previous studies had 
classified the study area as homogeneous [39] [40]. However, these previous studies classified the area from a purely physical perspective and not consider the biological communities. It has been shown that the change in a Celsius degree is enough to modify the behaviour of many of the marine species [54]. Therefore, from an ecological perspective, it was necessary to consider the oceanic province of the Colombian Pacific Basin as a heterogeneous area.

The distribution of surface salinity was inverse to temperature, but with its main axis coming from the north coast of Colombia. Coastal rainfall is what modulates the distribution of salinity in the Colombian Pacific Basin-CPB [40] and the North Pacific coast of Colombia is the place of greatest precipitation in the Tropic [55]. This could cause the E079 station to end up belonging more to the central sector, while the E109 to the north sector.

The distribution of the chlorophyll- $\alpha$ concentration is according to expectations. The Central sector has factors that generate higher productivity and more changes during the year. In this sector is Malpelo Island [56], which generates local conditions such as upwelling areas [57], benefiting phytoplankton. Furthermore, due to the movement of nutation of the earth, the ITCZ in the Central sector generates contrasting seasons during the year. In the Northern sector the ITCZ influence is more constant, so rainfall occurs throughout most of the year; different from the Southern sector, where the influence of the ITCZ is less, causing a prolonged drought during the year [31]. Productivity in the North and South sectors reflects this condition, with a lower concentration of chlorophyll- $\alpha$ and fewer changes during the year with respect to the Central sector.

In general, the behaviour of the environmental variables during the sampling time was influenced by climate variability similarly between the sectors and response patterns were evidenced according to ENSO conditions (Figure 5). Temperature, salinity and chlorophyll- $\alpha$ were more influenced in periods of La Niña. For the first variable there was a decrease in the values, while for the other two, the values increased.

The climate variability moderately changed the normal conditions during the study period, increasing or decreasing the values of the environmental variables analysed as described in other studies [58]. It was also determined that for the sampling periods no differentiation was observed in the impact according to the

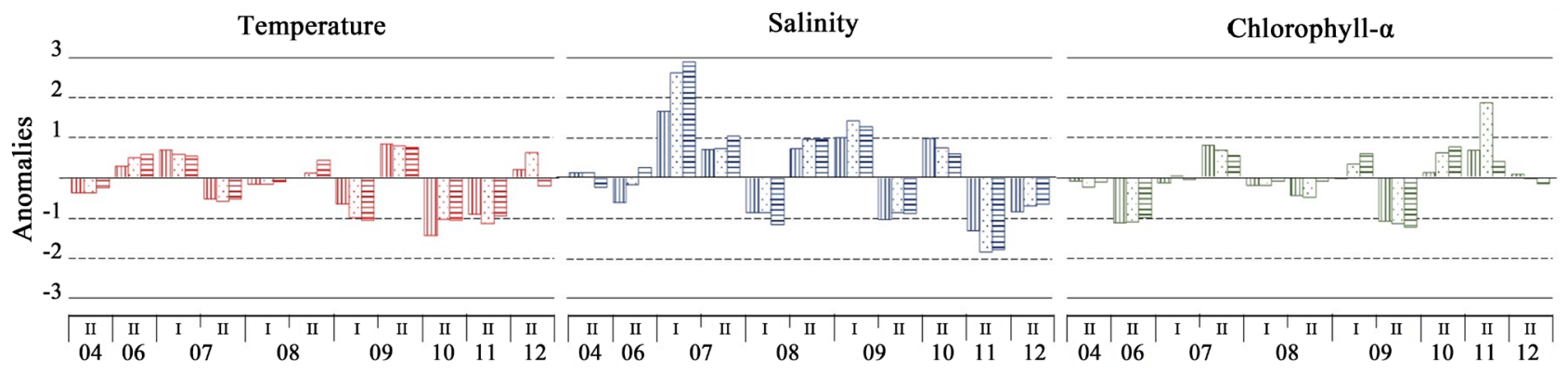

Figure 5. Anomalies of the environmental variables during the sampling moments (three months before and the sampling month). Vertical lines: northern sector; Dots: central sector; Horizontal lines: southern sector. 
sector. ENSO progressively impacts the different coastal regions of the Pacific, with the equatorial sector being the first to receive it. For the study area, the southern sector receives the impact two months after it occurs, while for the northern sector it can take up to four months [39]. The short time of involvement between sectors is reflected in the anomalies since only four months were considered.

The 14 identified species of holoplanktonic polychaetes belonged mostly to the Alciopidae and Lopadorrhynchidae families; only one species belonging to the family Iospilidae appeared. The frequency of occurrence of the species did not exceed 50\% of the samples reviewed. Lopadorrhynchus cf. henseni, L. cf. brevis and Pelagobia cf. longicirrata (Lopadorrhynchidae); and Plotohelmis cf. capitata, Rhynchonereella cf. petersii and $R$. cf. gracilis (Alciopidae) were the species that had occurrence frequencies greater than $10 \%$ and represented $85 \%$ of the total population density (Appendix-Figure A1).

The low frequency of occurrence and population density of holoplanktonic polychaetes was consistent with that registered in various studies conducted in open water of the Pacific Ocean [3] [4] [18] [59], contrary to what some authors have mentioned for studies done in coastal areas in other oceans [7] [60]. This difference in the ecological system can cause patterns to change [61]: low productivity areas similar to ocean province, have greater competition for the resource, while areas with external contributions (i.e. river plume or upwelling) as coastal sectors, allow all organisms to increase their densities more easily [62].

Regardless of the technical reasons related to capture and analysis methods [44], it was hypothesized that low frequencies of occurrence and population densities due to aspects such as the great mobility of holoplanktonic polychaetes [63], the rapid reaction of movement to water disturbances [44], the capacity that allows them to fractionate and regenerate again [47], and natural migrations to mesopelagic depths [3]. These factors would facilitate evasion to be captured. It could also be considered that, compared to copepods, holoplanktonic polychaetes are less adapted to the environment [64] and their presence in the zooplanktonic community is more recent than most other groups [65], which would give them disadvantages of colonization of niches.

The distribution and population density by sector and sampled period were different for all species (Figure 6) (Appendix-Table A3). The species of Alciopidae appeared in more sampling periods and were better distributed in the three sectors contrasting for to Lopadorrhynchidae species. In general, the species increased population densities at the end of the period studied, with a decrease in densities during 2009, as observed more clearly with Plotohelmis cf. capitata and Pelagobia cf. longicirrata (Figure 6(g), Figure 6(m)).

Of the Alciopidae, Rhynchonereella cf. moebii and Krohnia cf. lepidota appeared in two periods with averages of population density below 6 ind $/ 100 \mathrm{~m}^{3}$. The first species appeared during 2007 in the northern and central sectors, while the second was between the second semester of 2007 and the first of 2008 in the 
(a) Rhynchonereella cf. moebii (A)

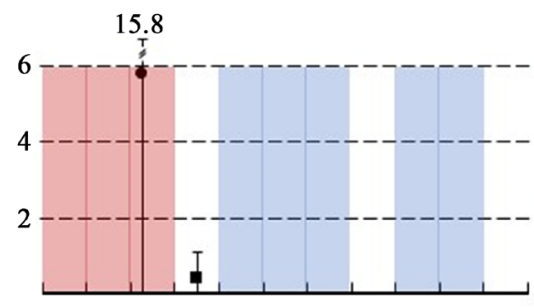

(d) Alciopina cf. parasitica (A)

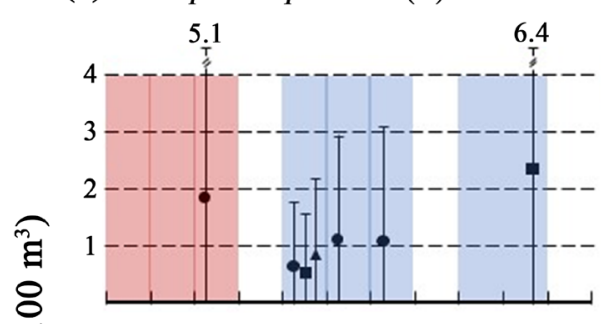

(g) Plotohelmis cf. capitata (A)

㝵
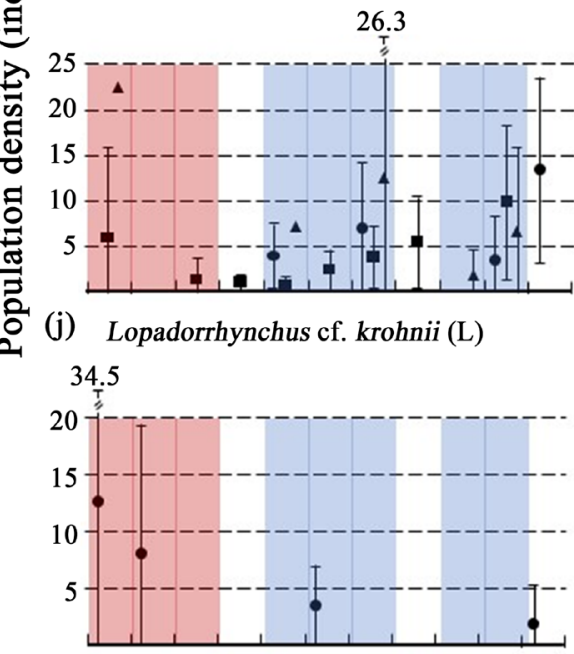

(m) Pelagobia cf. longicirrata (L)

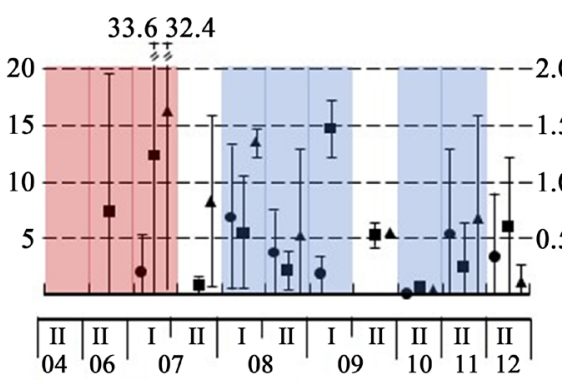

(b) Krohnia cf. lepidota (A)

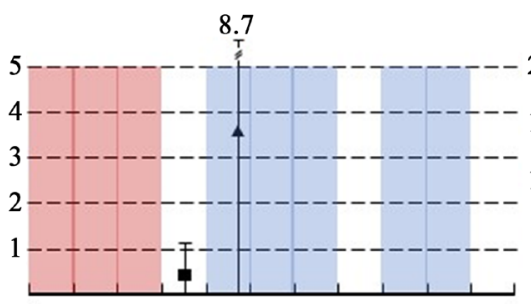

(e) Rhynchonereella cf. gracilis (A)

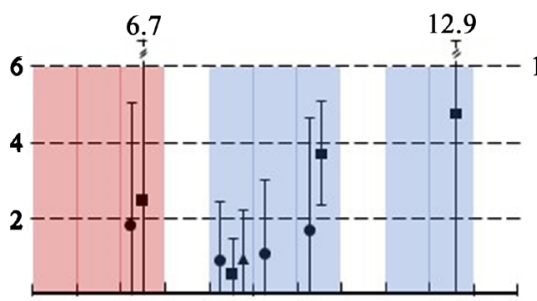

(h) Maupasia cf. gracilis (L)

(i) Pedisoma cf. curtum (L)

(c) Plotohelmis cf. alata (A)

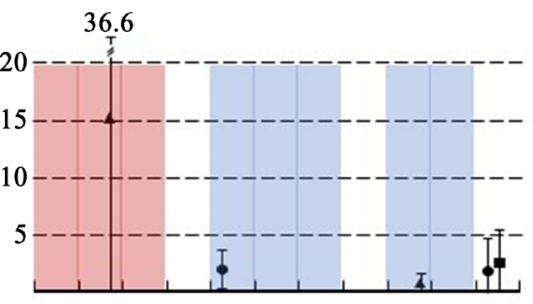

(f) Rhynchonereella cf. petersill (A)
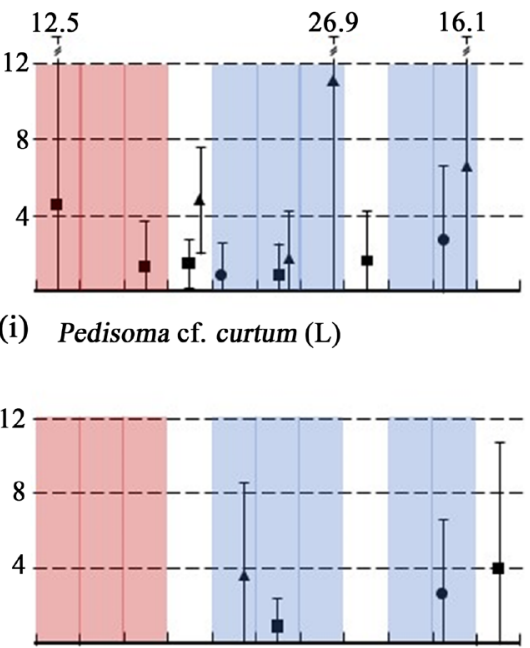

(k) Lopadorrhynchus cf. brevis (L)

(1) Lopadorrhynchus cf. henseni (L)

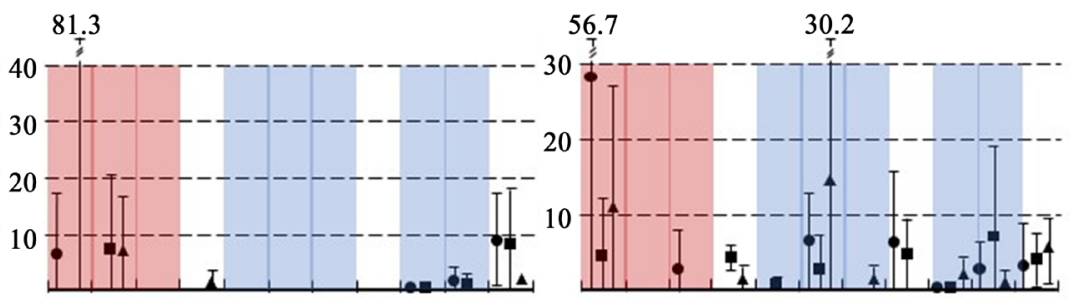

(n) Phalacrophorus cf. pictus (I)

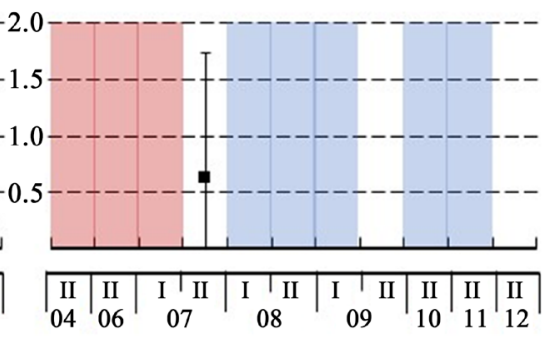

\section{Sampling time}

Figure 6. Mean population density and its standard deviations by sector of quantified holoplankton polychaete species during the 2004-2012 period. Square: northern sector; Circle: central sector; Triangle: southern sector. Red: El Niño condition; Blue: La Niña condition; No color: Neutral condition.

central and southern sectors (Figure 6(a), Figure 6(b)). Plotohelmis cf. alata and Alciopina cf. parasitica were collected in four and five sampling periods respectively, with 2008 being the best spatially represented for the second species. 
The average population densities were less than $5 \mathrm{ind} / 100 \mathrm{~m}^{3}$. Both species were collected in the three sectors, although for A.cf. parasitica it was more predominant in the northern sector, representing more than 50\% of appearance and density population (Figure 6(c), Figure 6(d)). Rhynchonereella cf. gracilis was collected in five sampled periods and, like $A$. cf. parasitica, 2008 was the year in which it was best represented spatially, but with average population densities less than $2 \mathrm{ind} / 100 \mathrm{~m}^{3}$. This species appeared in the three sectors, with the south being the least present (Figure 6(e)).

Rhynconereella cf. petersii and Plotohelmis cf. capitata, were those that occurred in the greatest number of sampled periods, with eight and ten times, respectively. Both species were not collected in 2006, and the case of $R$. cf. petersii, they did not appear in 2010 and 2012. The average population densities of $R$. cf. petersii were mostly below 5 ind $/ 100 \mathrm{~m}^{3}$; while for $P$. cf. capitata the average population densities were divided equally below and above the $5 \mathrm{ind} / 100 \mathrm{~m}^{3}$. Like Alciopina cf. parasitica, for $R$. cf. petersii and $P$. cf. capitata there was a decrease in population density during 2008. Both $R$. cf. petersii and $P$. cf. capitata were presented in the three sectors, the central one being the one with the highest frequency of appearance and the south with the highest population densities (Figure 6(f), Figure 6(g)).

As for the species of the Lopadorrhynchidae, specimens of Maupasia cf. gracilis were collected only during 2004 with an average density above 5 ind $/ 100 \mathrm{~m}^{3}$ (Figure 6(h)). Pedinosoma cf. curtum and Lopadorrhynchus cf. krohnii were presented during four sampled periods, the first species in the middle and end of the sampling period, while the second was distributed throughout the study period. The average population density of $P$. cf. curtum was close to $4 \mathrm{ind} / 100 \mathrm{~m}^{3}$, while for $L$. cf. krohnii it started above $10 \mathrm{ind} / 100 \mathrm{~m}^{3}$ and was decreasing over time to a value less than $5 \mathrm{ind} / 100 \mathrm{~m}^{3}$. Pedisoma cf. curtum was collected in all three sectors, while $L$. cf. krohnii only in the north (Figure 6(i), Figure 6(j)).

Lopadorrhynchus cf. brevis was collected at the beginning and end of the study period for a total of six of the sampled periods. It presented average population densities variable in time, being the highest at the beginning and end of the study (2004 and 2012), showing a similar pattern to some of the species of the Alciopidae with a decrease in densities towards the middle of the period. This species was present in all three sectors, being predominant in the south in the first sampling periods, and in the north and central the last sampled periods (Figure 6(k)).

The last two species of the Lopadorrhynchidae, Lopadorrhynchus cf. henseni and Pelagobia cf. longicirrata were collected in ten of the eleven sampling periods. They differed in that $L$. cf. henseni specimens were not collected in 2006 and $P$. cf. longicirrata in 2004. The population densities of both species varied over time, showing a pattern of peaks and valleys. Both species were found in all three sectors, however, the highest densities for $L$. cf. henseni were in the northern sector, while for $P$. cf. longicirrata in the central and southern areas (Figure 
6(1), Figure 6(m)). Finally, Phalacrophorus cf. pictus, of the Iospilidae family, appeared once during the second semester of 2007 in the central sector (Figure 6(n)).

Regarding the spatio-temporal distribution, Phalacrophorus cf. pictus, Alciopina cf. parasitica, Rhynchonereella cf. moebii, Kronhia cf. lepidota, Plotohelmis cf. alata, Maupasia cf. gracilis, Pedisoma cf. curtum, and Lopadorrhynchus cf. krohnii were considered rare species for $\mathrm{CPB}$, as has been recorded in other regions such a North Pacific, ETP or Caribbean Sea [7] [14] [17]. Not knowing the environmental requirements of these species, it is difficult to find an answer to this result. However, it seems that in some species its appearance coincided with some environmental characteristics. For example, L. cf. krohnii only appeared in the northern sector, when climate variability allowed increases in water temperature; $P$. cf curtum appeared when the intensity of La Niña began to decrease, and $A$. cf. parasitica had its greatest presence during La Niña from 2008-2009.

The other six species identified in the present study, Rhynchonereella cf. gracilis, $R$. cf. petersii, Plotohelmis cf. capitata, Lopadorrhynchus cf. brevis, L. cf. henseni and Pelagobia cf. longicirrata presented a wider geographical and temporal distribution. This same pattern has been described in other studies from Pacific Ocean [4] [9] [21], Atlantic Ocean and Caribbean Sea [63] [66] [67]. In all of them, $P$. cf. longicirrata was the most common species.

No statistical differences in population density between sectors were determined from the three most frequent species of both families, however, climate variability did influence the Lopadorrhynchus cf. henseni and L. cf. brevis (Kruskall-Wallis p-value $<0.05$ ). In both cases, the population densities during the El Niño periods were significantly higher compared to the periods with La Niña and neutral for the first of the species, and with La Niña for the second (Dunn p-value < 0.02) (Appendix-Table A4, Figure A2).

The different sectors found from the environmental variables did not influence population densities in the six most common species. This could be due to the fact that the environmental differences were not marked enough to generate a natural barrier [68], and that the species have sufficient tolerance ranges to be able to live in other regions [3] [6] [69]. The latter fact could be verified with the environmental ranges of the species in the present study.

The holoplanktonic polychaetes presented different ranges of the environmental variables conditioned with the frequency of appearance (Figure 7). In the case of the species of the Alciopidae they tended to warmer temperatures, and higher salinities and chlorophyll- $\alpha$ concentrations, while the species of the Lopadorrhynchidae tended to colder temperatures and less salinity waters but with high chlorophyll- $\alpha$ concentrations. The most frequent species with the highest population densities (Plotohelmis cf. capitata and Pelagobia cf. longicirrata) were present in the entire range of temperature, salinity and chlorophyll- $\alpha$ concentration. The species with intermediate frequency and population density (Rhynchonereella cf. petersii, $R$. cf. gracilis, Lopadorrhynchus cf. henseni, and $L$. cf. brevis) 
Species

(A) Plotohelmis cf. capitata

(A) Rhynchonereella cf. petersill (13)

(A) Rhynchonereella cf. gracilis (12)

(A) Alciopina cf. parasitica

(A) Plotohelmis cf. alata

(A) Rhynchonereella cf. moebii

(A) Krohnia cf. lepidota

(L) Pelagobia cf. longicirrata

(L) Lopadorrhynchus cf. henseni (31)

(L) Lopadorrhynchus cf. brevis (16)

(L) Lopadorrhynchus cf. krohnii (5)

(L) Pedisoma cf. curtum

(L) Maupasia cf. gracilis

(I) Phalacrophorus ef. pictus
(4)

(1)

(n)

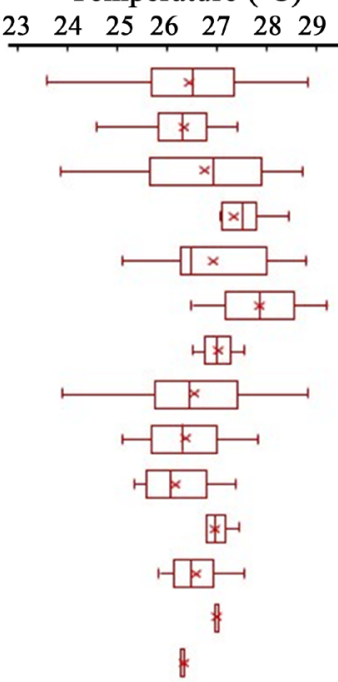

Chlorophyll- $\alpha\left(\mu \mathrm{g} / \mathrm{m}^{3}\right)$

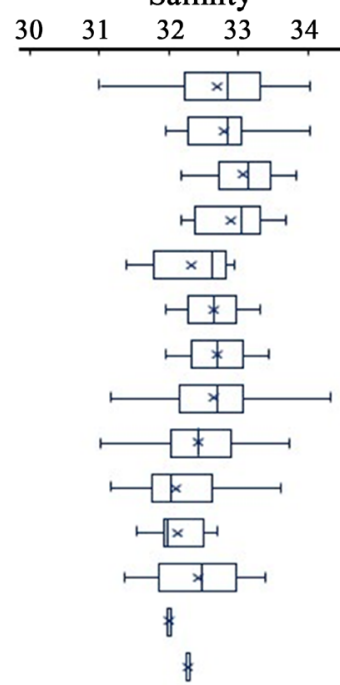

400

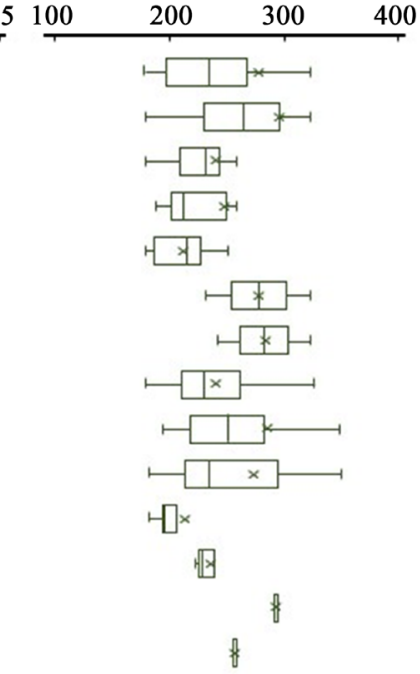

Figure 7. Ranges of environmental variables where holoplankton polychaete species appeared in the oceanic province of Colombian Pacific Basin during 2004-2012. (n): number of samples; (A): Alciopidae; (L): Lopadorrhynchidae; (I): Iospilidae.

coincided with the decrease in the range of at least one of the variables.

Less frequent species with low population densities (Alciopina cf. parasitica, Plotohelmis cf. alata, Lopadorrhynchus cf. krohnii and Pedisoma cf. curtum) coincided with a greater decrease in environmental ranges in general, with tendencies to warmer waters and medium salinities. They differ in chlorophyll- $\alpha$ concentrations, in which species of the Lopadorrhynchidae tended to appear with low concentrations. Finally, the species that were collected at two or fewer sampling times (Rhynchonereella cf. moebii, Krohnia cf. lepidota, Maupasia cf. gracilis, and Phalacrophorus $\mathrm{cf}$. pictus) tended to appear with average values of each of the variables (Figure 7).

Regarding the correlations between population density of species and environmental variables, significant and positive statistical differences with temperature were found in Lopadorrhynchus cf. henseni (Pearson 0.32; p-value < 0.1 ) and L. brevis (Pearson 0.60; p-value < 0.05), with salinity in Pelagobia cf. longicirrata (Pearson 0.30; $\mathrm{p}$-value $<0.1$ ) and with chlorophyll- $\alpha$ concentration in Rhynchonereella cf. gracilis (Pearson 0.80; p-value < 0.05). Rhynchonereella cf. petersii was the only species to having a negative statistical significance with temperature (Pearson -0.58; p-value < 0.1) (Appendix-Table A5, Figure A3).

The population density of Lopadorrhynchus cf. henseni and L. cf. brevis showed a positive correlation with temperature and increased the population densities with El Niño compared to La Niña and Neutral condition. There are no data that support an explanation, but it was hypothesized that their densities are related to the fact that these species are considered omnivorous [2], added to the evidence that during El Niño the presence and abundance of omnivorous species increases [70] [71].

No evidence why Rhynchonereella cf. petersii showed negative correlation between population density and temperature. According to Jumars et al. [2], this 
species is omnivorous with a tendency to herbivore. Continuing with the approach to the increase in omnivores due to the influence of El Niño, it can be hypothesized that this species is herbivorous in the study area; therefore it is affected with food decrease.

The decrease of population density by El Niño has also been described for the entire assembly of holoplanktonic polychaetes during the period with the El Niño of 1997, one of the strongest in history [21]. El Niño condition in the present study it can be considered weak due to its low intensity and duration. This reason allows us to infer that $R$. cf. petersii may be the only one that is at the limit of environmental tolerance with respect to the other holoplanktonic polychaetes.

Rhynchonereella cf. gracilis showed a contrary pattern to that found in coastal regions with respect to correlation between population density and chlorophyll- $\alpha$ concentration [3] [21]. It is a species considered carnivorous [2], so possibly its positive correlation is due to the presence of its prey. However, there is no evidence to support it.

Finally, the population density of Pelagobia cf. longicirrata showed a positive correlation with salinity. As has happened with the species analyzed above, there are no previous studies that have related these variables and attributed any reason. It is hypothesized for this case that its morphology, a depressed body, different from the other identified species [18] may allow it an advantage to move when water density increases due to salinity. This morphological advantage, in turn, would explain why it is the most frequent species of holoplankton polychaetes. It would have an advantage in capturing prey from the pico- and nanoplankton since these organisms, being smaller, would find it difficult to move to avoid being predated [72].

\section{Conclusions}

This study provides new ecological information on 14 species of holoplanktonic polychaetes with respect to environmental variables of temperature, salinity, and chlorophyll- $\alpha$ concentration, as well as climate variability in a tropical region.

In ecological terms, the Colombian Pacific basin during the 2004-2012 climate variability presented a spatial differentiation from north to south, with the greatest differences being found between the North and South sectors, while the central sector was the most fluctuating annually. Climate variability during the study period was dominated by La Niña and did not differentially influence the sectors.

The present study confirms that the planktonic assemblages of the oceanic province present a high frequency and low population densities of holoplanktonic polychaetes. The 14 species identified did not show a spatially or temporally differentiated distribution. Only the species Lopadorrhynchus cf. henseni and $L$. cf. brevis were influenced by climate variability, increasing their populations with the influence of El Niño. 
Finally, five species showed correlations with the environmental variables. $L$. cf. henseni and L. cf. brevis had a positive correlation with temperature; Rhynchonereella cf. petersii had a negative correlation with temperature, and $R$. cf. gracilis and Pelagobia. cf. longicirrata had a positive correlation with chlorophyll- $\alpha$ concentration and salinity, respectively.

\section{Contributors}

J.M.G.-S. carried out the separation, quantification and taxonomic identification of organisms, data analysis and wrote the manuscript as part of his Ph.D. thesis. A.C.-O. carried out the taxonomic identification and validation of the organisms. N.H.C. guided the structuring, edited, and made the final revision of the manuscript. The authors declare that they have no conflict of interest

\section{Acknowledgements}

We express our gratitude to 1) CECIMAR of the Universidad Nacional de Colombia (UNAL) Caribbean headquarters for allowing us to review the samples and have all the logistic support of the laboratory, 2) the Universidad del Valle, administrators of the analysed samples and allowed their unrestricted use, 3) to the MAKURIWA museum of INVEMAR for allowing work in their laboratories and guarding the biological samples throughout the process and 4) COLCIENCIAS for financial support to JMG-S. to devote full time to doctoral work and completion of the internship. Personally, J.M.G.-S. Thanks to his parents Alicia and José Ángel for the support always and in every way to complete the doctoral stage. This manuscript is equivalent to contribution No. 513 of CECIMAR and No. CTRB-1295 of INVEMAR.

\section{Financing}

This work was supported by the Departamento Administrativo de Ciencia, Tecnología e Innovación-COLCIENCIAS with the grant of national doctorates [Grant number 727 to J.M.G.-S.]; the Universidad Nacional de Colombia-UNAL, Caribbean headquarters [39195 to J.M.G.-S.]; and the Museo de Historia Natural Marina de Colombia-MAKURIWA of the Instituto de Investigaciones Marinas y Costeras-INVEMAR contributes with the loan of the equipment, and the laboratory for the research in question.

\section{Conflicts of Interest}

The authors declare no conflicts of interest regarding the publication of this paper.

\section{References}

[1] Steinberg, D.K. and Landry, M.R. (2017) Zooplankton and the Ocean Carbon Cycle. Annual Review of Marine Science, 9, 413-444. https://doi.org/10.1146/annurev-marine-010814-015924 
[2] Jumars, P.A., Dorgan, K.M. and Lindsay, S.M. (2015) Diet of Worms Emended: An Update of Polychaete Feeding Guilds. Annual Review of Marine Science, 7, 497-520. https://doi.org/10.1146/annurev-marine-010814-020007

[3] Guglielmo, R., Gambi, M.C., Granata, A., Guglielmo, L. and Minutoli, R. (2014) Composition, Abundance, and Distribution of Holoplanktonic Polychaetes within the Strait of Magellan (Southern America) in Austral Summer. Polar Biology, 37, 999-1015. https://doi.org/10.1007/s00300-014-1496-8

[4] Jiménez-Cueto, S., Suárez-Morales, E. and Morales-Ramírez, A. (2012) Algunos poliquetos holoplanctónicos (Annelida: Polychaeta) del Parque Nacional Isla del Coco, Costa Rica. Revista de Biología Tropical, 60, 207-222.

[5] Fernández-Álamo, M.A. and Thuesen, E.V. (1999) Polychaeta. In: Boltovskoy, D., Ed., South Atlantic Zooplankton, Backhuys Publishers, Leiden, Netherland, 595-619.

[6] Bilbao, M., Palma, S. and Rozbaczylo, N. (2008) First Records of Pelagic Polychaetes in Southern Chile (Boca del Guafo-Elefantes Channel). Latin American Journal of Aquatic Research, 36, 129-135.

[7] Márquez-Rojas, B., Díaz-Díaz, O. and Balza, M.A. (2013) Holoplanktonic Polychaetes (Annelida: Polychaeta) from Venezuela. Pan-American Journal of Aquatic Science, 8, 160-165.

[8] Uttal, L. and Buck, K.R. (1996) Dietary Study of the Midwater Polychaete Poeobius meseres in Monterey Bay, California. Marine Biology, 125, 333-343. https://doi.org/10.1007/BF00346314

[9] Fernández-Álamo, M.A. and Sanvicente-Anorve, L. (2005) Holoplanktonic Polychaetes from the Gulf of Tehuantepec, Mexico. Cahiers de Biologie Marine, 46, 227-239.

[10] Knox, G. (1994) The Biology of the Southern Ocean. Cambridge University Press, Cambridge, United Kingdom.

[11] Guglielmo, L., Minutoli, R., Bergamasco, A., Granata, A., Zagami, G. and Antezana, T. (2011) Short-Term Changes in Zooplankton Community in Paso Ancho Basin (Strait of Magellan): Functional Trophic Structure and Diel Vertical Migration. Polar Biology, 34, 1301-1317. https://doi.org/10.1007/s00300-011-1031-0

[12] Suárez-Morales, E., Jiménez-Cueto, S. and Salazar-Vallejo, S.I. (2005) Catálogo de los poliquetos pelágicos (Polychaeta) del Golfo de México y mar Caribe mexicano. El Colegio de la Frontera Sur (ECOSUR), Campeche, México.

[13] Salazar-Vallejo, S.I. and Londoño-Mesa, M.H. (2004) Lista de especies y bibliografía de poliquetos (Polychaeta) del Pacífico Oriental Tropical. Anales del Instituto de Biología, Universidad Nacional Autónoma de México, Serie Zoología, 75, 9-97.

[14] Fernández-Álamo, M.A. (2006) Composition, Abundance, and Distribution of Holoplanktonic polychaetes from the Expedition "El Golfo 6311-12" of Scripps Institution of Oceanography. Scientia Marina, 70, 209-215.

https://doi.org/10.3989/scimar.2006.70s3209

[15] Dales, K.P. (1957) Pelagic Polychaetes of the Pacific Ocean. Bulletin of the Scripps Institution of Oceanography, 7, 99-168.

[16] Støp-Bowitz, C. (1992) Polychêtes pélagiques des campagnes de 'L'Ombago' dans les eaux équatoriales et tropicales ouest-africaines. Institut Francais de Recherche Scientifique pour le Développement en Coopération, France.

[17] Buzhinskaja, G.N. (2017) Descriptions of Pedinosoma curtum Reibisch from North-West Pacific and a Late Larva of Pedinosoma polaris sp. nov. from the Arctic Basin (Polychaeta: Phyllodocida: Lopadorhynchidae). Zoosystematica Rossica, 26, 3-10. https://doi.org/10.31610/zsr/2017.26.1.3 
[18] Fernández-Álamo, M.A. (1983) Los poliquetos pelágicos (Annelida-Polychaeta) del Pacífico Tropical Oriental: sistemática y zoogeografía. PhD Thesis, Universidad Nacional Autónoma de México, Mexico City.

[19] Fernández-Álamo, M.A. (2000) Tomopterids (Annelida: Polychaeta) from the Eastern Tropical Pacific Ocean. Bulletin of Marine Science, 67, 45-53.

[20] Fernández-Álamo, M.A. (2004) Distribution of Holoplanktonic Typhloscolecids (Annelida-Polychaeta) in the Eastern Tropical Pacific Ocean. Journal of Plankton Research, 26, 647-657. https://doi.org/10.1093/plankt/fbh063

[21] Carvajal-Pinilla, L.A., Vergara-Castillo, C.F. and López-Peralta, R.H. (2009) Chaetognatha, Thaliacea, Euphausiacea and Pelagic Polychaeta in the Colombian Pacific Ocean during Two Periods in 1996 (La Niña) and Two Periods in 1997 (El Niño). Revista Facultad de Ciencias Básicas, 5, 172-185.

[22] Gajbhiye, S.N. (2002) Zooplankton-Study Methods, Importance and Significant Observations. Proceedings of the National Seminar on Creeks, Estuaries and Mangroves Pollution and Conservation, Mumbai, India, 28-30 November 2002, 21-27.

[23] Turner, J.T. (2004) The Importance of Small Planktonic Copepods and Their Roles in Pelagic Marine Food Webs. Zoological Studies, 43, 255-266.

[24] Mair, L., Hill, J.K., Fox, R., Botham, M., Brereton, T. and Thomas, C.D. (2014) Abundance Changes and Habitat Availability Drive Species' Responses to Climate Change. Nature Climate Change, 4, 127-131. https://doi.org/10.1038/nclimate2086

[25] McQuatters-Gollop, A., Johns, D.G., Bresnan, E., Skinner, J., Rombouts, I., Stern, R., Aubert, A., Johansen, M., Bedford, J. and Knights, A. (2017) From Microscope to Management: The Critical Value of Plankton Taxonomy to Marine Policy and Biodiversity Conservation. Marine Policy, 83, 1-10.

https://doi.org/10.1016/j.marpol.2017.05.022

[26] Ohlberger, J. (2013) Climate Warming and Ectotherm Body Size-From Individual Physiology to Community Ecology. Functional Ecology, 27, 991-1001.

https://doi.org/10.1111/1365-2435.12098

[27] Uribe-Palomino, J., López, R., Gibbons, M.J., Gusmão, F. and Richardson, A.J. (2018) Siphonophores from Surface Waters of the Colombian Pacific Ocean. Journal of the Marine Biological Association of the United Kingdom, 99, 67-80. https://doi.org/10.1017/S0025315417002065

[28] Molina-González, O., Lavaniegos, B.E., Gómez-Valdés, J. and de la Cruz-Orozco, M. (2018) Holoplanktonic mollusks off Western Baja California during the weak El Niño 2006-07 and further transition to La Niña. American Malacological Bulletin, 36, 79-95. https://doi.org/10.4003/006.036.0112

[29] Velasco, J., Gutiérrez-Cánovas, C., Botella-Cruz, M., Sánchez-Fernández, D., Arribas, P., Carbonell, J.A., Millán, A. and Pallarés, S. (2019) Effects of Salinity Changes on Aquatic Organisms in a Multiple Stressor Context. Philosophical Transactions of the Royal Society B: Biological Sciences, 374, Article ID: 20180011. https://doi.org/10.1098/rstb.2018.0011

[30] Wang, C. and Fiedler, P.C. (2006) ENSO Variability and the Eastern Tropical Pacific: A Review. Progress in Oceanography, 69, 239-266. https://doi.org/10.1016/j.pocean.2006.03.004

[31] Amador, J.A., Rivera, E.R., Durán-Quesada, A.M., Mora, G., Sáenz, F., Calderón, B. and Mora, N. (2016) The Easternmost Tropical Pacific. Part I: A Climate Review. Revista de Biología Tropical, 64, S1-S22. https://doi.org/10.15517/rbt.v64i1.23409

[32] Amador, J.A., Durán-Quesada, A.M., Rivera, E.R., Mora, G., Sáenz, F., Calderón, B. and Mora, N. (2016) The Easternmost Tropical Pacific. Part II: Seasonal and In- 
traseasonal Modes of Atmospheric Variability. Revista de Biología Tropical, 64, S23S57. https://doi.org/10.15517/rbt.v64i1.23409

[33] Villegas-Bolaños, N.L. (2003) Variación anual del contenido de calor de la capa activa del Pacífico colombiano. Boletín Científico CCCP, 10, 33-46.

[34] Akbari, E., Alavipanah, S., Jeihouni, M., Hajeb, M., Haase, D. and Alavipanah, S. (2017) A Review of Ocean/Sea Subsurface Water Temperature Studies from Remote Sensing and Non-Remote Sensing Methods. Water, 9, Article No. 936. https://doi.org/10.3390/w9120936

[35] Rebstock, G.A. (2002) Climatic Regime Shifts and Decadal-Scale Variability in Calanoid Copepod Populations off Southern California. Global Change Biology, 8, 71-89. https://doi.org/10.1046/j.1365-2486.2002.00456.x

[36] Eiane, K., Espinasse, M. and Espinasse, B. (2018) Environmental Effects on Zooplankton Abundance on a Sub-Arctic Shelf off Northern Norway. Aquatic Biology, 27, 75-86. https://doi.org/10.3354/ab00697

[37] Gómez, F.A., Lee, S.-K., Hernández, F.J., Chiaverano, L.M., Muller-Karger, F.E. Liu, Y. and Lamkin, J.T. (2019) ENSO-Induced Co-Variability of Salinity, Plankton Biomass and Coastal Currents in the Northern Gulf of Mexico. Scientific Reports, 9 , Article No. 178. https://doi.org/10.1038/s41598-018-36655-y

[38] Giraldo-López, A., Velasco, E. and Martínez, T.I. (2014) Grazing Impact of Calanoid Copepods in the Colombian Pacific Ocean. Revista de Ciencias, Universidad del Valle, 18, 11-25.

[39] Cabarcas-Mier, A.M. (2017) Anomalías de temperatura superficial del mar y su relación con eventos atmosféricos en la Cuenca Pacífica colombiana. MSc Thesis, Escuela Naval de Cadetes Almirante Padilla, Cartagena, Colombia.

[40] Málikov, I. (2000) Determinación de zonas homogéneas del Pacífico colombiano. Final Technical Report. Centro Control Contaminación del Pacífico, 16 p.

[41] León-Aristizabal, G.E., Zea-Mazo, J.A. and Eslava-Ramírez, J.A. (2000) Circulación general del Trópico y la Zona de Confluencia Intertropical en Colombia. $\mathrm{Me}$ tereología Colombiana, No. 1, 31-38.

[42] O’Brien, T.D., Lorenzoni, L., Isensee, K. and Valdés, L. (2017) What Are Marine Ecological Time Series Telling Us about the Ocean? A Status Report. IOC Technical Series, International Olympic Committee, Paris, France, 297 p.

[43] National Oceanic and Atmospheric Administration (2019) Southern Oscillation Index (SOI). https://www.ncdc.noaa.gov/teleconnections/enso/indicators/soi/

[44] Boltovskoy, D. (1999) South Atlantic zooplankton. Backhuys, Leiden, Netherlands.

[45] Permanent Commission of the South Pacific_CPPS (2021) Permanent Commission of the South Pacific. Guayaquil, Ecuador. http://cpps-int.org/index.php

[46] Orensanz, J. and Ramírez, F. (1973) Taxonomía y distribución de los poliquetos pelágicos del Atlántico sudoccidental. Boletín del Instituto de Biología Marina de Mar del Plata, No. 21, 1-118.

[47] de León-González, J.A., García-Garza, M.E., Peña-Rivera, A., Carreña-Parra, L.F., Salazar-Vallejo, S.I., Solís-Weiss, V. and Bastida-Zavala, J.R. (2009) Poliquetos (Annelida: Polychaeta) de México y América Tropical. Universidad Autónoma de Nuevo León, Monterrey.

[48] World Register of Marine Species (2020) WoRMS Editorial Board. http://www.marinespecies.org/

[49] Clarke, K.R. and Gorley, R.N. (2015) PRIMER v7: User Manual/Tutorial. PRIMER-E, Ltd., Plymouth, United Kingdom. 
[50] Hidalgo, P., Escribano, R. and Morales, C.E. (2005) Annual Life Cycle of the Copepod Eucalanus inermis at a Coastal Upwelling Site off Mejillones $\left(23^{\circ} \mathrm{S}\right)$, Northern Chile. Marine Biology, 146, 995-1003. https://doi.org/10.1007/s00227-004-1487-3

[51] Shimode, S., Takahashi, K., Shimizu, Y., Nonomura, T. and Tsuda, A. (2012) Distribution and Life History of the Planktonic Copepod, Eucalanus californicus, in the Northwestern Pacific: Mechanisms for Population Maintenance within a High Primary Production Area. Progress in Oceanography, 96, 1-13. https://doi.org/10.1016/j.pocean.2011.08.002

[52] Zaiontz, C. (2018) Real Statistics Using Excel. http://www.real-statistics.com

[53] Kessler, W.S. (2006) The Circulation of the Eastern Tropical Pacific: A Review. Progress in Oceanography, 69, 181-217. https://doi.org/10.1016/j.pocean.2006.03.009

[54] Richardson, A.J. (2008) In Hot Water: Zooplankton and Climate Change. ICES Journal of Marine Science, 65, 279-295. https://doi.org/10.1093/icesjms/fsn028

[55] Rodríguez-Rubio, E. (2013) A Multivariate Climate Index for the Western Coast of Colombia. Advances in Geosciences, 33, 21-26.

https://doi.org/10.5194/adgeo-33-21-2013

[56] Marcaillou, B., Charvis, P. and Collot, J.-Y. (2006) Structure of the Malpelo Ridge (Colombia) from Seismic and Gravity Modelling. Marine Geophysical Researches, 27, 289-300. https://doi.org/10.1007/s11001-006-9009-y

[57] Quintanilla, E., Madurell, T., Wilke, T. and Sánchez, J.A. (2019) Dynamic Interplay of ENSO Events and Local Hydrodynamic Parameters Drives Demography and Health Status of Gorgonian Sea Fan Populations on a Remote Tropical Eastern Pacific Island. Frontiers in Marine Science, 6, Article No. 694. https://doi.org/10.3389/fmars.2019.00694

[58] Christensen, J.H., Krishna-Kumar, K., Aldrian, E., An, S.-I., Cavalcanti, I.F.A., de Castro, M., Dong, W., Goswami, P., Hall, A., Kanyanga, J.K., Kitoh, A., Kossin, J., Lau, N.-C., Renwick, J., Stephenson, D.B., Xie, S.-P. and Zhou, T. (2013) Climate Phenomena and Their Relevance for Future Regional Climate Change. In: Stocker, T.F., Qin, D., Plattner, G.-K., Tignor, M., Allen, S.K., Boschung, J., Nauels, A., Xia, Y., Bex, V. and Midgley, P.M., Eds., Climate Change 2013: The Physical Science Basis. Contribution of Working Group I to the 5th Assessment Report of the Intergovernmental Panel on Climate Change, Cambridge University Press, Cambridge and New York, 1217-1308.

[59] Fernández-Álamo, M.A. (1996) Holoplanktonic polychaetes off the Southwestern Coast of Baja California, México, in March, 1997. Anales del Instituto de Biología, Universidad Nacional Autónoma de México, Serie Zoología, 67, 51-66.

[60] Díaz-Díaz, O., Bone, D., Rodríguez, C.T. and Delgado-Blas, V.H. (2017) Poliquetos de Sudamerica. Boletín del Instituto Oceanográfico de Venezuela, Venezuela.

[61] Griffiths, J.R., Hajdu, S., Downing, A.S., Hjerne, O., Larsson, U. and Winder, M. (2016) Phytoplankton Community Interactions and Environmental Sensitivity in Coastal and Offshore Habitats. Oikos, 125, 1134-1143. https://doi.org/10.1111/oik.02405

[62] Pelayo-Martínez, G., Olivos-Ortiz, A., Franco-Gordo, C., Quijano-Scheggia, S., Gavino-Rodríguez, J., Kono-Martínez, T. and Castro-Ochoa, F. (2017) Physical, Chemical and Zooplankton Biomass Variability (Inshore Offshore) of Mexican Central Pacific during El Niño-La Niña 2010. Latin American Journal of Aquatic Research, 45, 67-78. 
[63] Jiménez-Cueto, S. and Suárez-Morales, E. (2008) An Account of Alciopina, Torrea, and Rhynconereella (Polychaeta: Alciopidae) of the Western Caribbean Sea. The Belgian Journal of Zoology, 138, 70-80.

[64] Kiørboe, T. (2011) What Makes Pelagic Copepods So Successful? Journal of Plankton Research, 33, 677-685. https://doi.org/10.1093/plankt/fbq159

[65] Rigby, S. and Milsom, C.V. (2000) Origins, Evolution, and Diversification of Zooplankton. Annual Review of Ecology and Systematics, 31, 293-313. https://doi.org/10.1146/annurev.ecolsys.31.1.293

[66] Cárdenas-Oliva, A.V., Díaz, O.F. and Márquez, B. (2010) Caracterización taxonómica de los poliquetos holoplanctónicos (Annelida: Polychaeta) de la plataforma norte de la Península de Paria y Golfo de Paria, Venezuela. Boletín del Instituto Oceanográfico de Venezuela, 49, 53-63.

[67] Collazo, N., Hernández, F., Soldevilla, F., Vera, A., Núñez, J. and Fraile-Nuez, E. (2017) Poliquetos planctónicos relacionados con enclaves de vulcanismo reciente en Canarias. Vieraea, 45, 89-118.

[68] McManus, M.A. and Woodson, C.B. (2012) Plankton Distribution and Ocean Dispersal. Journal of Experimental Biology, 215, 1008-1016.

https://doi.org/10.1242/jeb.059014

[69] Fernández-Álamo, M.A. (1991) Holoplanktonic Polychaetes from the Gulf of California: August-September 1977. CalCOFI Report, 32, 97-104.

[70] Castillo, F. and Vizcaino, Z. (1992) Los indicadores biológicos del fitoplancton y su relación con el fenómeno de El Niño 1991-92 en el Pacífico colombiano. Boletín Científico CIOH, No. 12, 13-22.

[71] Medina-Campos, L. (1997) Composición y comportamiento del fitoplancton en el área del Pacífico colombiano, años 1995-1997. Boletín Científico CCCP, No. 6, 95-108.

[72] Kiørboe, T. (2008) A Mechanistic Approach to Plankton Ecology. Princeton University Press, Princeton. https://doi.org/10.1515/9780691190310. 


\section{Appendix}

Supplementary data from sampling stations and environmental data; results of population analyses; and data on population density by species.

Table A1. Oceanographic and climatic data sources used for the present study. SST: sea surface temperature; SSS: sea surface salinity; SSC: sea surface chlorophyll- $\alpha$ concentration; SOI: Southern Oscillation Index. (): no units.

\begin{tabular}{|c|c|c|c|c|c|c|c|}
\hline Variable & Type & Time & Periodicity & Unit & $\begin{array}{l}\text { Spatial } \\
\text { resolution }\end{array}$ & Source & Availability \\
\hline SST & Oceanographic & 1981-2015 & Monthly & ${ }^{\circ} \mathrm{C}$ & Sampling points & $\begin{array}{l}\text { Avhrrsst y } \\
\text { Modis }\end{array}$ & $\begin{array}{l}\text { Cabarcas (2017) } \\
\text { (Personal request) }\end{array}$ \\
\hline SSS & Oceanographic & $1950-2015$ & Monthly & () & Sampling points & Hadley-EN4 & $\begin{array}{c}\text { COPEPODITE } \\
\text { (https://www.st.nmfs.noaa.gov/copepodite/) }\end{array}$ \\
\hline SSC & Oceanographic & 1998-2016 & Monthly & $\mathrm{mg} / \mathrm{m}^{3}$ & Sampling points & OCCCI-v3.1 & $\begin{array}{c}\text { COPEPODITE } \\
\text { (https://www.st.nmfs.noaa.gov/copepodite/) }\end{array}$ \\
\hline SOI & Climatic & $1951-2016$ & Monthly & () & Sampling points & NOAA & $\begin{array}{c}\text { NOAA } \\
\frac{\text { (https://www.ncdc.noaa.gov/teleconnections/ }}{\text { enso/indicators/soi/) }}\end{array}$ \\
\hline
\end{tabular}

Table A2. Information stations sampled. The sample identifier (ID.) is the combination of the station number, the semester, and the sampled year.

\begin{tabular}{|c|c|c|c|c|c|}
\hline \multirow{2}{*}{ Station } & \multicolumn{4}{|c|}{ Sampling time } & \multirow{2}{*}{ ID. } \\
\hline & Year & Semester & Date & Hour & \\
\hline \multirow{11}{*}{ E075 } & 2004 & 2 & $28 / 09 / 2004$ & 05:30 a.m. & E075.2.4 \\
\hline & 2006 & 2 & \multicolumn{2}{|c|}{ No information. } & E075.2.6 \\
\hline & 2007 & 1 & $05 / 02 / 2007$ & 10:28 a.m. & E075.1.7 \\
\hline & 2007 & 2 & $15 / 09 / 2007$ & 06:00 p.m. & E075.2.7 \\
\hline & 2008 & 1 & $16 / 03 / 2008$ & 02:53 a.m. & E075.1.8 \\
\hline & 2008 & 2 & $15 / 09 / 2008$ & 05:46 a.m. & E075.2.8 \\
\hline & 2009 & 1 & $18 / 03 / 2009$ & 04:55 p.m. & E075.1.9 \\
\hline & 2009 & 2 & $02 / 10 / 2009$ & 05:38 a.m. & E075.2.9 \\
\hline & 2010 & 2 & $02 / 10 / 2010$ & 12:00 p.m. & E075.2.10 \\
\hline & 2011 & 2 & $01 / 11 / 2011$ & 08:56 p.m. & E075.2.11 \\
\hline & 2012 & 2 & $09 / 09 / 2012$ & 07:38 p.m. & E075.2.12 \\
\hline & 2004 & 2 & $26 / 09 / 2004$ & 10:00 p.m. & E077.2.4 \\
\hline & 2006 & 2 & $19 / 09 / 2006$ & 02:43 p.m. & E077.2.6 \\
\hline & 2007 & 1 & $06 / 02 / 2007$ & 11:00 p.m. & E077.1.7 \\
\hline E077 & 2007 & 2 & $14 / 09 / 2007$ & 03:17 p.m. & E077.2.7 \\
\hline & 2008 & 1 & $17 / 03 / 2008$ & 09:44 a.m. & E077.1.8 \\
\hline & 2008 & 2 & $16 / 09 / 2008$ & 07:58 p.m. & E077.2.8 \\
\hline & 2009 & 1 & $17 / 03 / 2009$ & 12:56 a.m. & E077.1.9 \\
\hline
\end{tabular}




\section{Continued}

\begin{tabular}{|c|c|c|c|c|c|}
\hline & 2009 & 2 & $30 / 09 / 2009$ & 03:11 p.m. & E077.2.9 \\
\hline & 2010 & 2 & $30 / 9 / 2010$ & 09:10 p.m. & E077.2.10 \\
\hline & 2011 & 2 & $01 / 11 / 2011$ & 02:37 p.m. & E077.2.11 \\
\hline & 2012 & 2 & $10 / 09 / 2012$ & 01:18 a.m. & E077.2.12 \\
\hline \multirow{11}{*}{ E079 } & 2004 & 2 & $04 / 10 / 2004$ & 10:30 p.m. & E079.2.4 \\
\hline & 2006 & 2 & $19 / 09 / 2006$ & 07:42 a.m. & E079.2.6 \\
\hline & 2007 & 1 & $14 / 02 / 2007$ & 12:49 p.m. & E079.1.7 \\
\hline & 2007 & 2 & $25 / 09 / 2007$ & 05:22 p.m. & E079.2.7 \\
\hline & 2008 & 1 & $25 / 03 / 2008$ & $10: 38$ a.m. & E079.1.8 \\
\hline & 2008 & 2 & $23 / 09 / 2008$ & 06:32 p.m. & E079.2.8 \\
\hline & 2009 & 1 & $06 / 03 / 2009$ & 11:42 a.m. & E079.1.9 \\
\hline & 2009 & 2 & $20 / 09 / 2009$ & 10:26 p.m. & E079.2.9 \\
\hline & 2010 & 2 & $21 / 09 / 2010$ & 07:20 a.m. & E079.2.10 \\
\hline & 2011 & 2 & $24 / 10 / 2011$ & 05:10 a.m. & E079.2.11 \\
\hline & 2012 & 2 & $11 / 09 / 2012$ & 06:20 a.m. & E079.2.12 \\
\hline \multirow{11}{*}{ E081 } & 2004 & 2 & $7 / 10 / 2004$ & 02:30 a.m. & E081.2.4 \\
\hline & 2006 & 2 & $16 / 09 / 2006$ & 05:46 p.m. & E081.2.6 \\
\hline & 2007 & 1 & $16 / 02 / 2007$ & 08:50 p.m. & E081.1.7 \\
\hline & 2007 & 2 & $27 / 09 / 2007$ & 09:47 a.m. & E081.2.7 \\
\hline & 2008 & 1 & $27 / 03 / 2008$ & 01:40 a.m. & E081.1.8 \\
\hline & 2008 & 2 & $25 / 09 / 2008$ & 05:44 p.m. & E081.2.8 \\
\hline & 2009 & 1 & $04 / 03 / 2009$ & 04:30 a.m. & E081.1.9 \\
\hline & 2009 & 2 & $18 / 09 / 2009$ & 09:11 a.m. & E081.2.9 \\
\hline & 2010 & 2 & $19 / 09 / 2010$ & 06:26 a.m. & E081.2.10 \\
\hline & 2011 & 2 & $21 / 10 / 2011$ & 08:51 a.m. & E081.2.11 \\
\hline & 2012 & 2 & $6 / 09 / 2012$ & 07:20 a.m. & E081.2.12 \\
\hline \multirow{9}{*}{ E107 } & 2004 & 2 & $09 / 10 / 2004$ & 06:30 p.m. & E107.2.4 \\
\hline & 2006 & 2 & & There are no samples. & \\
\hline & 2007 & 1 & $06 / 02 / 2007$ & 12:45 a.m. & E107.1.7 \\
\hline & 2007 & 2 & & There are no samples. & \\
\hline & 2008 & 1 & $16 / 03 / 2008$ & 03:23 p.m. & E107.1.8 \\
\hline & 2008 & 2 & $15 / 09 / 2008$ & 10:15 p.m. & E107.2.8 \\
\hline & 2009 & 1 & $18 / 03 / 2009$ & 12:33 a.m. & E107.1.9 \\
\hline & 2009 & 2 & $01 / 10 / 2009$ & 02:11 p.m. & E107.2.9 \\
\hline & 2010 & 2 & $01 / 10 / 2010$ & 08:50 p.m. & E107.2.10 \\
\hline
\end{tabular}




\section{Continued}

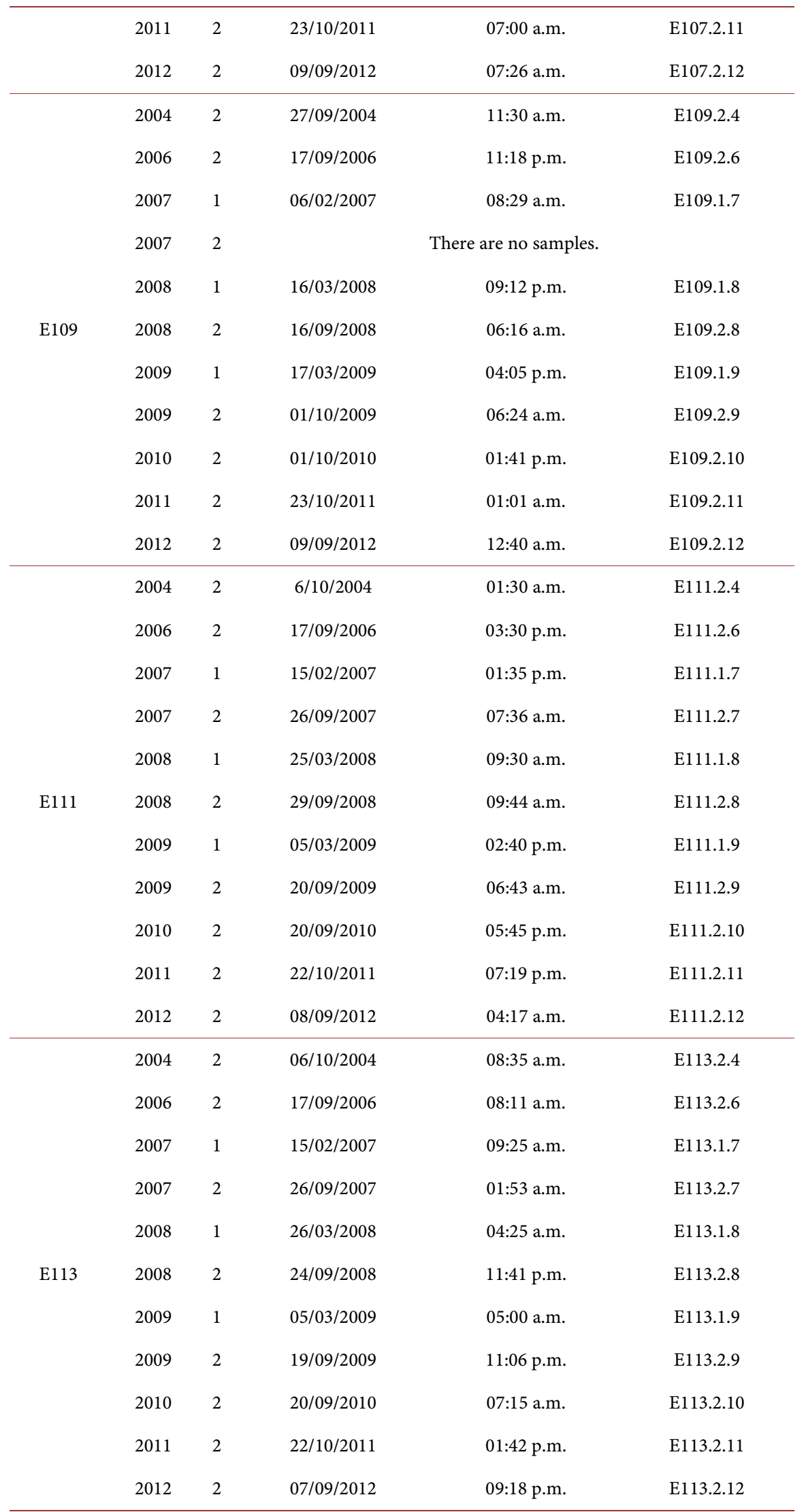


Table A3. Population density (ind $/ 100 \mathrm{~m}^{3}$ ) of holoplankton polychaetes found in the Pacific Ocean Basin of Colombia during the climate variability from 2004 to 2012.

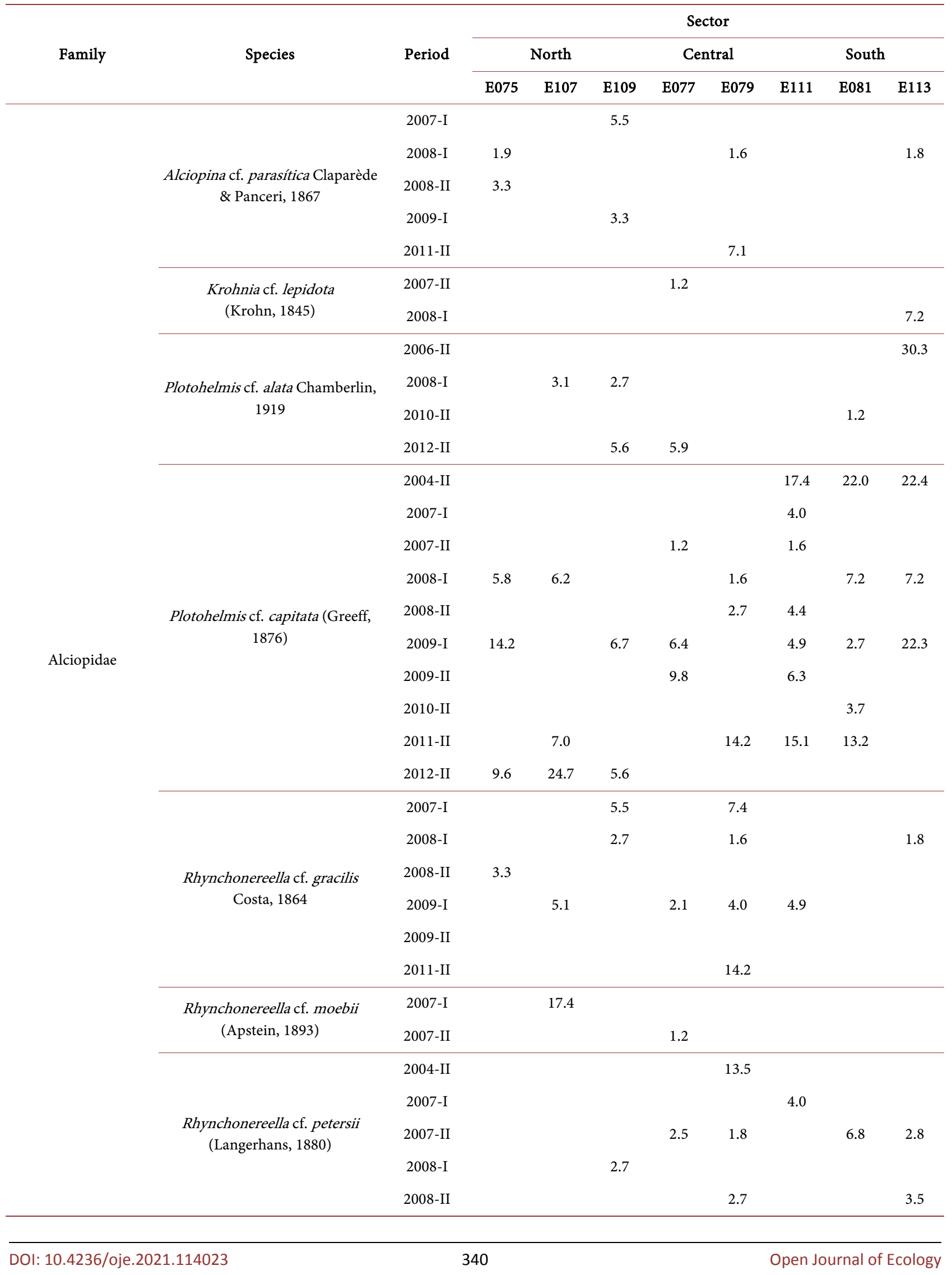




\section{Continued}

\begin{tabular}{|c|c|c|c|c|c|c|c|c|c|c|}
\hline & & 2009-I & & & & & & & & 22.3 \\
\hline & & 2009-II & & & & & 4.6 & & & \\
\hline & & 2011-II & & & 5.4 & & & & & 13.3 \\
\hline & & 2004-II & 18.9 & & & & & & & 67.3 \\
\hline & & 2006-II & & & & & 22.1 & & 14.1 & \\
\hline & & 2007-II & & & & & & & & 2.8 \\
\hline & $\begin{array}{l}\text { Lopadorrhynchus cf. brevis } \\
\text { Grube } 1855\end{array}$ & 2009-II & & & & & & & & \\
\hline & & 2010-II & 1.2 & & & & & 0.6 & & \\
\hline & & 2011-II & & 3.5 & & & & 3.0 & & \\
\hline & & 2012-II & & 9.9 & 16.8 & & 6.0 & 18.8 & 1.7 & 2.2 \\
\hline & & 2004-II & 56.7 & 28.5 & & & 13.5 & & & 22.4 \\
\hline & & 2007-I & & 8.7 & & & & & & \\
\hline & & 2007-II & & & & 2.5 & 5.5 & 4.9 & & 2.8 \\
\hline & & 2008-I & & & & & 1.6 & & & \\
\hline & Lopadorrhynchus cf. henseni & 2008-II & 13.2 & 6.7 & & & 8.0 & & 25.6 & 3.5 \\
\hline & Reibisch, 1893 & 2009-I & & & & & & & 2.7 & \\
\hline & & 2009-II & 13.0 & & & 4.9 & 9.3 & & & \\
\hline & & 2010-II & & 0.6 & & & 0.6 & & 3.7 & \\
\hline & & 2011-II & & & 5.4 & & & 21.2 & 1.9 & \\
\hline & & 2012-II & 9.6 & & & 5.9 & & 6.3 & 8.4 & 2.2 \\
\hline & & 2004-II & 37.8 & & & & & & & \\
\hline \multirow[t]{18}{*}{ Lopadorrhynchidae } & Lopadorrhynchus cf. krohnii & 2006-II & & & 16.0 & & & & & \\
\hline & (Claparède, 1870) & 2008-II & & 6.7 & 3.9 & & & & & \\
\hline & & 2012-II & & & 5.6 & & & & & \\
\hline & $\begin{array}{c}\text { Maupasia cf. gracilis (Reibisch, } \\
\text { 1893) }\end{array}$ & 2004-II & 18.9 & & & & & & & \\
\hline & & $2008-\mathrm{I}$ & & & & & & & 7.2 & \\
\hline & Pedinosoma cf. curtum Reibisch, & 2008-II & & & & & 2.7 & & & \\
\hline & 1895 & 2011-II & & & 5.4 & & & & & \\
\hline & & 2012-II & & & & 11.8 & & & & \\
\hline & & 2006-II & & & & 21.8 & & & & \\
\hline & & 2007-I & 5.9 & & & & 36.9 & & 27.6 & 5.1 \\
\hline & & 2007-II & & & & & & 1.6 & 13.7 & 2.8 \\
\hline & & $2008-\mathrm{I}$ & & 12.5 & 8.1 & 9.6 & 6.6 & & 14.5 & 12.6 \\
\hline & Pelagobia cf. longicirrata Greeff, & 2008-II & 3.3 & & 7.8 & 3.5 & 2.7 & & & 10.6 \\
\hline & 1879 & 2009-I & 3.5 & 1.7 & & 17.2 & 12.0 & 14.6 & & \\
\hline & & 2009-II & & & & 4.9 & 4.6 & 6.3 & & 5.5 \\
\hline & & 2010-II & & 0.6 & & & 1.2 & 0.6 & 0.6 & \\
\hline & & 2011-II & & & 10.8 & & 7.1 & & & 13.3 \\
\hline & & 2012-II & & 9.9 & & 5.9 & 11.9 & & & 2.2 \\
\hline Iospilidae & $\begin{array}{c}\text { Phalacrophorus cf. pictus Greeff, } \\
1879\end{array}$ & 2007-II & & & & & 1.8 & & & \\
\hline
\end{tabular}


(a)

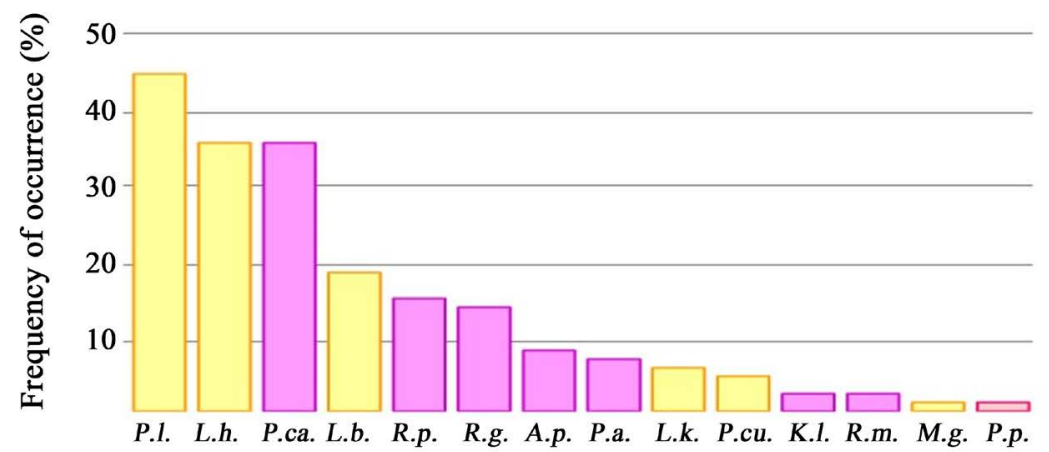

(b)
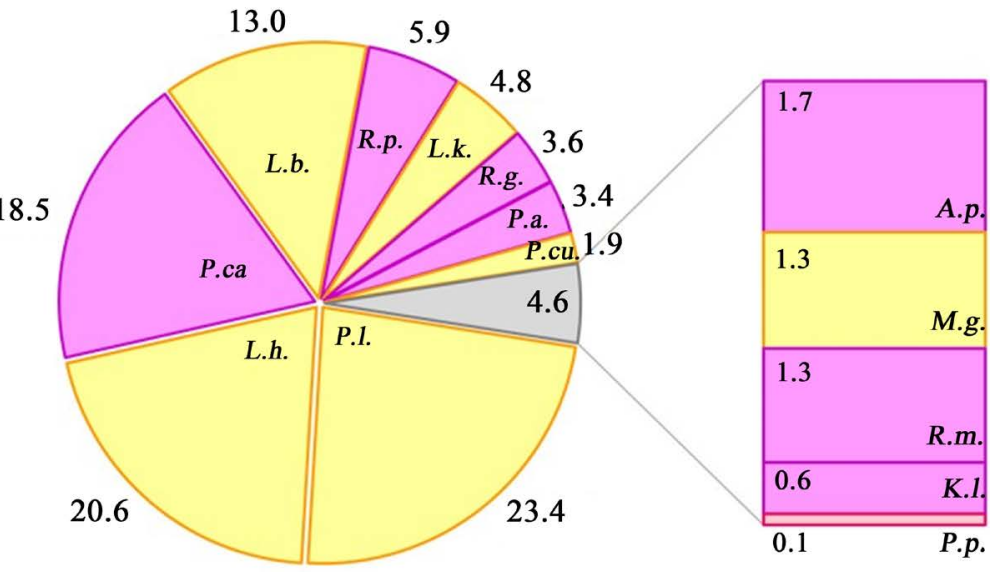

Alciopidae

Lopadorrhynchidae

Iospilidae

Figure A1. Proportion (\%) of the biological attributes of quantified holoplanktonic polychaetes during the 2004-2012 period. A. Frequency of occurrence; B. Population density. A.p.: Alciopina cf. parasitica; K.l.: Krohnia cf. lepidota; P.a.: Plotohelmis cf. alata; P.ca.: Plotohelmis cf. capitata; R.g.: Rhynchonereella cf. gracilis, R.m.: Rhynchonereella cf. moebii; R.p.: Rhynchonereella cf. petersii; L.b.: Lopadorrhynchus cf. brevis, L.h.: Lopadorrhynchus cf. henseni; L.k.: Lopadorrhynchus cf. krohnii; M.g.: Maupasia cf. gracilis; P.cu.: Pedinosoma cf. curtum; P.l.: Pelagobia cf. longicirrata; P.p.: Phalacrophorus cf. pictus.

Table A4. P-values of the Kruskall-Wallis test to determine if there are differences in the population densities of holoplankton polychaete species between sectors (North, Central and South) and by climate variability (El Niño-No, La Niña-Na and Neutral-N). ${ }^{*}$ p-value $<0.05 .{ }^{* *}$-value $<0.017$.

\begin{tabular}{|c|c|c|c|}
\hline Species & Sector & Climate Variability & Dunn test \\
\hline Plotohelmis cf. capitata & 0.17 & 0.25 & \\
\hline Rhynchonereella cf. petersii & 0.33 & 0.36 & \\
\hline Rhynchonereella cf. gracilis & 0.45 & - & \\
\hline Pelagobia cf. longicirrata & 0.63 & 0.13 & \\
\hline Lopadorrhynchus cf. henseni & 0.18 & $0.01^{*}$ & $0.011^{* *}(\mathrm{No} / \mathrm{N})-0.003^{* *}(\mathrm{No} / \mathrm{Na})$ \\
\hline Lopadorrhynchus cf. brevis & 0.93 & $0.02^{*}$ & $0.004^{\star *}(\mathrm{No} / \mathrm{Na})$ \\
\hline
\end{tabular}




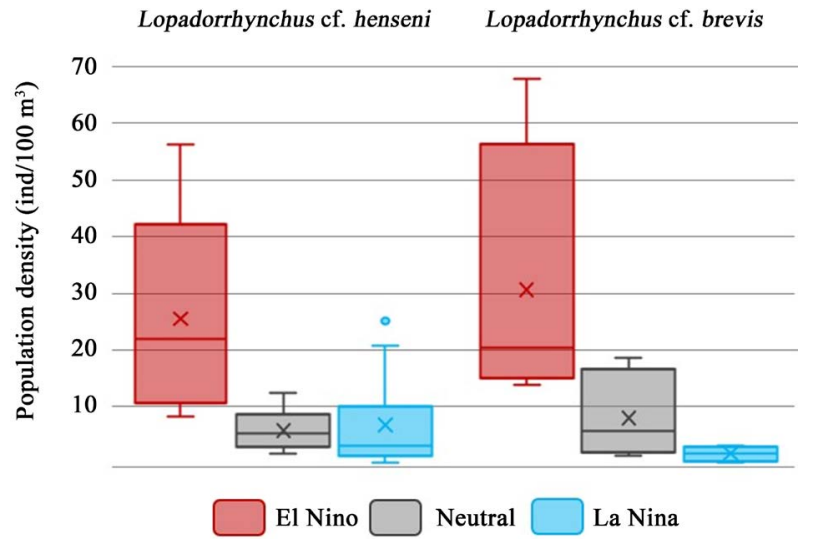

Figure A2. Graphical representation of the population density of two species of holoplanktonic polychaetes with statistical significance from the Kruskal-Wallis tests.

Table A5. Correlations between population density and environmental variables. n: number of data used; L: data transformed with logarithm base 10 to obtain normality; D: population density; T: temperature; S: salinity; C: chlorophyll- $\alpha$ concentration; P: Pearson test; S: Spearman test; ${ }^{*} \mathrm{p}<0.1 ;{ }^{* *} \mathrm{p}<0.05$.

\begin{tabular}{cccccc}
\hline Species & $\mathbf{n}$ & Data & Temperature & Salinity & Chlorophyll \\
\hline Pelagobia cf. longicirrata & 39 & L(D); T; S; L(C) & (P) 0.14 & (P) $0.30^{*}$ & (P) 0.07 \\
Lopadorrhynchus cf. henseni & 31 & L(D); T; S; C & (P) $0.32^{*}$ & (P) 0.01 & (S) -0.01 \\
Lopadorrhynchus cf. brevis & 16 & L(D); T; S; C & (P) $0.60^{* *}$ & (P) 0.12 & (S) -0.04 \\
Lopadorrhynchus cf. krohnii & 5 & D; T; S; C & (S) 0.60 & (S) -0.30 & (S) 0.10 \\
Plotohelmis cf. capitata & 31 & L(D); T; S; C & (P) -0.14 & (P) -0.24 & (P) 0.24 \\
Rhynchonereella cf. petersii & 13 & L(D); T; S; C & (P) $-0.58^{*}$ & (P) 0.20 & (S) 0.12 \\
Rhynchonereella cf. gracilis & 11 & L(D); T; S; C & (P) -0.17 & (P) -0.17 & (P) $0.80^{* *}$ \\
Alciopina cf. parasitica & 7 & D; T; S; C & (S) -0.32 & (S) -0.14 & (S) 0.14 \\
Plotohelmis cf. alata & 6 & D; T; S; C & (S) 0.09 & (S) -0.09 & (S) 0.09 \\
\hline
\end{tabular}

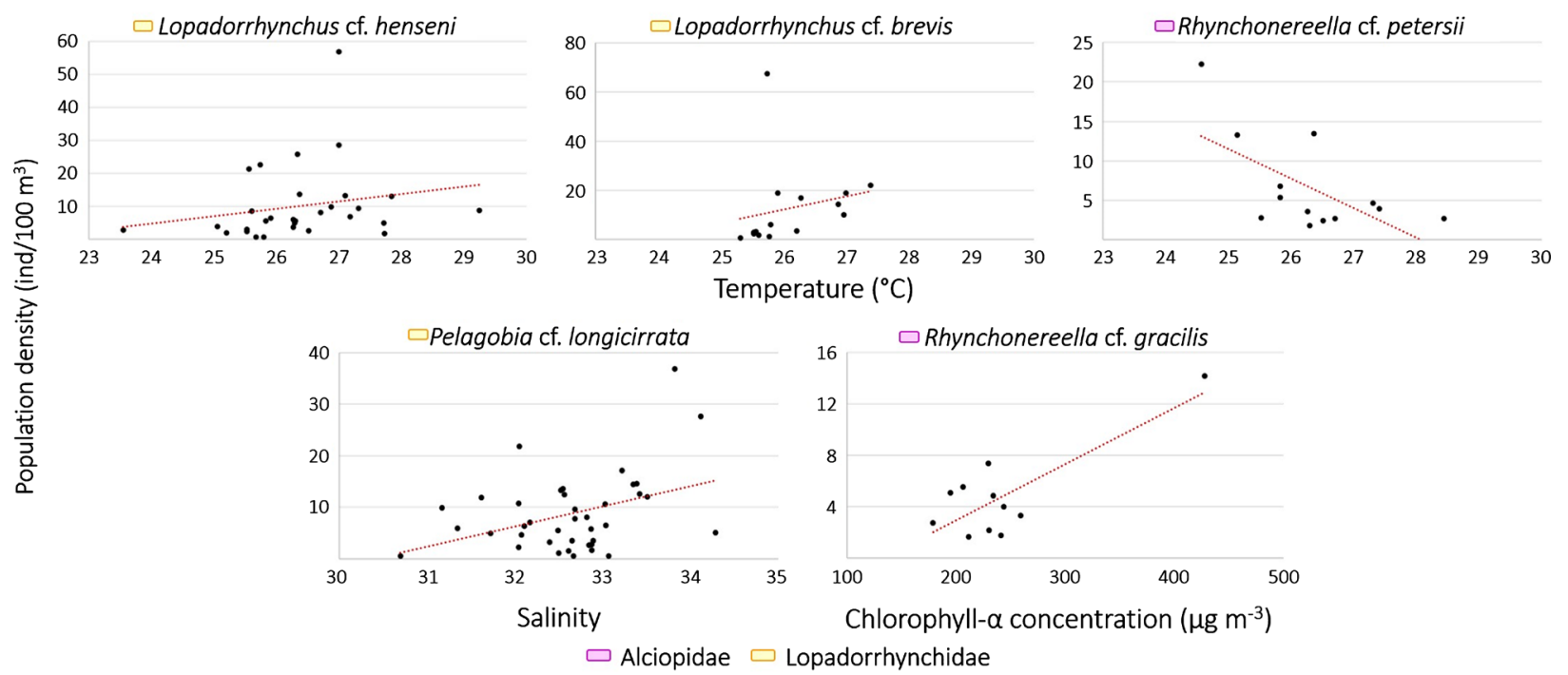

Figure A3. Relations between environmental variables and population density of holoplanktonic polychaete species with statistical significance based on correlation tests. 